\title{
Subversive Landscapes: The Symbolic Representation of Socialist Landscapes in the Visual Arts of the German Democratic Republic
}

\section{Oliver Sukrow}

To cite this article: Oliver Sukrow (2017) Subversive Landscapes: The Symbolic Representation of Socialist Landscapes in the Visual Arts of the German Democratic Republic, Rethinking Marxism, 29:1, 96-141, DOI: $10.1080 / 08935696.2017 .1316108$

To link to this article: http://dx.doi.org/10.1080/08935696.2017.1316108

Published online: 26 Jun 2017.

Submit your article to this journal $\llbracket$

Џلll Article views: 148

Q View related articles ๘

View Crossmark data \lceil

Citing articles: 1 View citing articles $\sqsubset$ 


\title{
Subversive Landscapes: The Symbolic Representation of Socialist Landscapes in the Visual Arts of the German Democratic Republic
}

\section{Oliver Sukrow}

\begin{abstract}
This essay on the visual representation of landscapes in the German Democratic Republic (GDR) suggests the historical and aesthetic significance of romantic traditions of the nineteenth century for the Socialist cultural practice of the GDR as well as for theoretical reflections on the importance of landscape and nature for the development of a Socialist society. With such a comparative approach, we can not only interpret philosophical work by Lothar Kühne as a Marxist reflection on romantic notions of the importance of landscape but we can also trace the stylistic influence of romantic artists like Caspar David Friedrich on the GDR's Socialist landscape painting. More specifically, the essay shows how Wolfgang Mattheuer became the foremost GDR landscape painter by adapting, transforming, and reevaluating Friedrich's art. Relying on the tradition of German romanticism, Mattheuer developed a new genre of Socialist landscape representation comprising both important artworks and tools of critique.
\end{abstract}

Key Words: German Democratic Republic, Landscape, Wolfgang Mattheuer, Romanticism, Visual Art

The appearance of the landscape is the visible expression of a particular era. —Reinhold Lingner, "Auswertung der 'Landschaftsdiagnose"”

\section{How Caspar David Friedrich's Rediscovery and Wolfgang Mattheuer's Breakthrough Triggered the GDR's Sotzromantizm}

Over forty years ago, in 1974, the German Democratic Republic (GDR) celebrated the 2ooth anniversary of the Romantic painter Caspar David Friedrich (I774-I840) with a conference in Friedrich's hometown Greifswald and with a major retrospective in Dresden, where he lived most of his life (see Imig 1974; Staatliche Kunstsammlungen Dresden 1974; and see figs. I-2). The celebrations of Friedrich's 


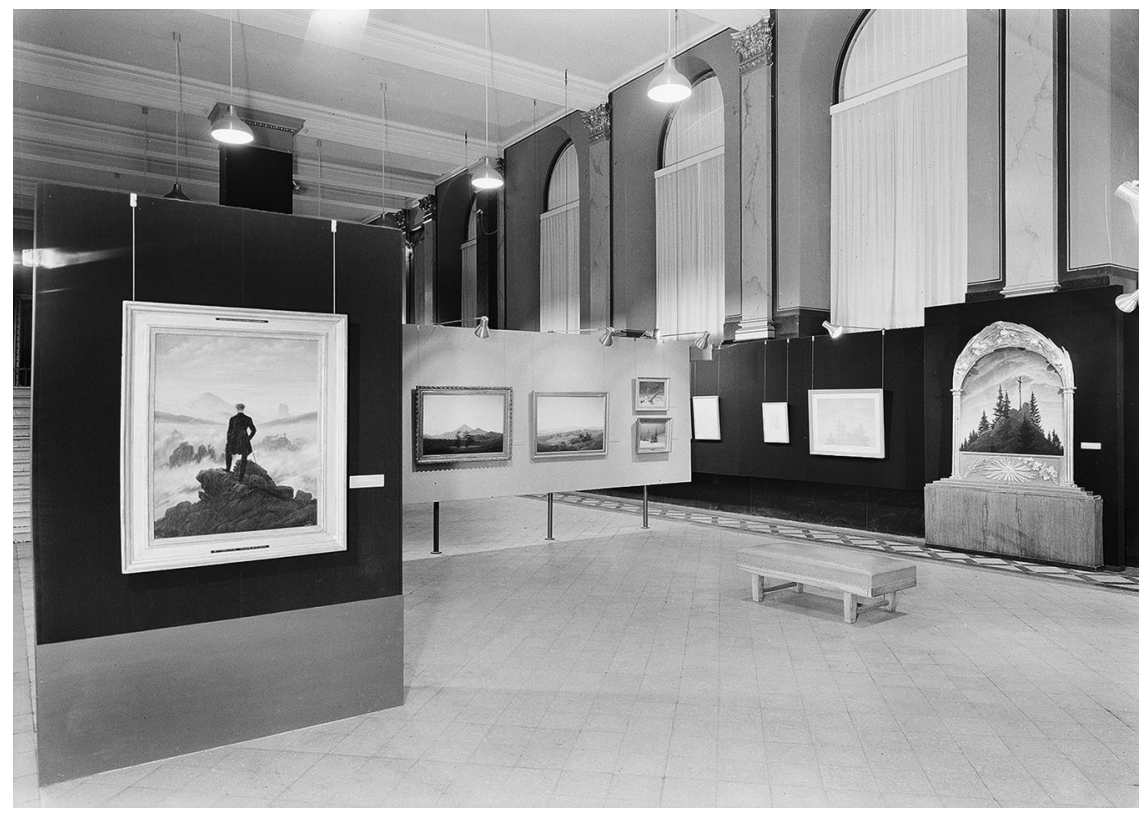

Fig. I. View of the Foyer, Caspar David Friedrich and His Circle, Dresden exhibition, 1974-5, (c) SLUB Dresden, Deutsche Fotothek, Waltraud Rabich.

artistic achievements in the genre of landscape painting marked the climax of an ongoing controversial, dynamic, and complex debate on romantic art and romanticism in the GDR. While until the I96os, the romantic movement was condemned and criticized by Marxist intellectuals for ignoring sociopolitical realities after the French Revolution of 1789 and for an antirationalistic mystifying of the world, various developments paved the way for a positive and productive connection of Socialist culture to its nineteenth-century ancestors. Processes, which can be understood within the framework of Sotzromantizm as "an autonomous (and relatively coherent) form of historical imagination" offered a "form of critical engagement with actually existing Socialism." The integration of Friedrich's oeuvre into the art canon of Socialist East Germany can be seen as a sign of those developments within the framework of Sotzromantizm and were part of the early critical engagement with the Socialist society of the GDR of the I970s.

In the same vein, Manfred Bachmann (I928-200I), the director of the State Art Collections of Dresden, said in his opening speech for the Friedrich exhibition of 1974 that Friedrich's art "embodies the best traditions of the progressive bourgeoisie" and can therefore be seen as a fruitful source of inspiration for the visual art of the Socialist presence (Bachmann 1976, II) - a claim which found its

I. See "CFP: Romantic Subversions of Soviet Enlightenment (Princeton, 9-IO May 20I4)," HArtHist, 2I November 20I3, http://arthist.net/archive/6476. 


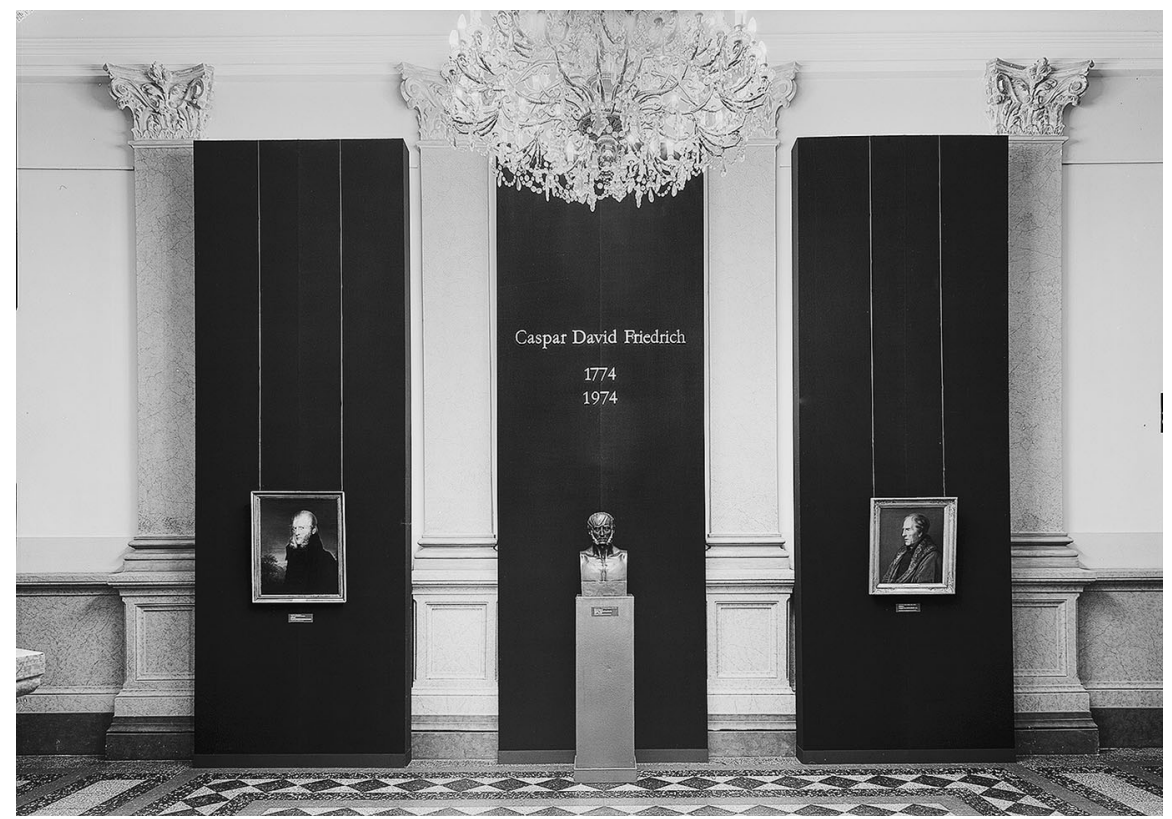

Fig. 2. View of the Klingersaal, Caspar David Friedrich and His Circle, Dresden exhibition, 1974-5, ( ) SLUB Dresden, Deutsche Fotothek, Waltraud Rabich.

equivalent in popular culture and mass media of the GDR (see figs. 3-4). At the same time as Friedrich's art was rediscovered, conferences and exhibitions focused on a contemporary East German artist, whose oeuvre was also dominated by the depiction of landscapes: Wolfgang Mattheuer (1927-2004) was seen as inheritor of the German romantic tradition in the genre of landscape (Palme I974, I38-4I; Feist 1974, 20-I). Even a smaller exhibition in the New Masters Gallery in Dresden was devoted to his works, accompanying Friedrich's retrospective. Mattheuer was interpreted and pushed forward as a modern Socialist neo-romantic artist, as an artist who inherited and triumphed over Friedrich's art (Kuhirt 1975, 28I-5; see fig. 5). In 1974, it seemed that the aesthetic dogma of a naturalistic Socialist Realism and its critique of "Romanticism" were overcome and replaced by a more differentiated approach (Goeschen 200I). No longer was "Romantic belief seen as a serious threat to the Socialist ideology" (Hertel 20I4, 248). Friedrich's landscapes were purged of the spiritual element. Instead art-historical research and ideology emphasized the political and social elements of his landscape paintings. At that moment, Friedrich won his place in the collective memory of East German society again as he had under other German regimes from the early twentieth century (Busch 200I, 52I).

To move beyond the well-established formalistic part of an art-historical comparison between Mattheuer and Friedrich and to show new perspectives on how 


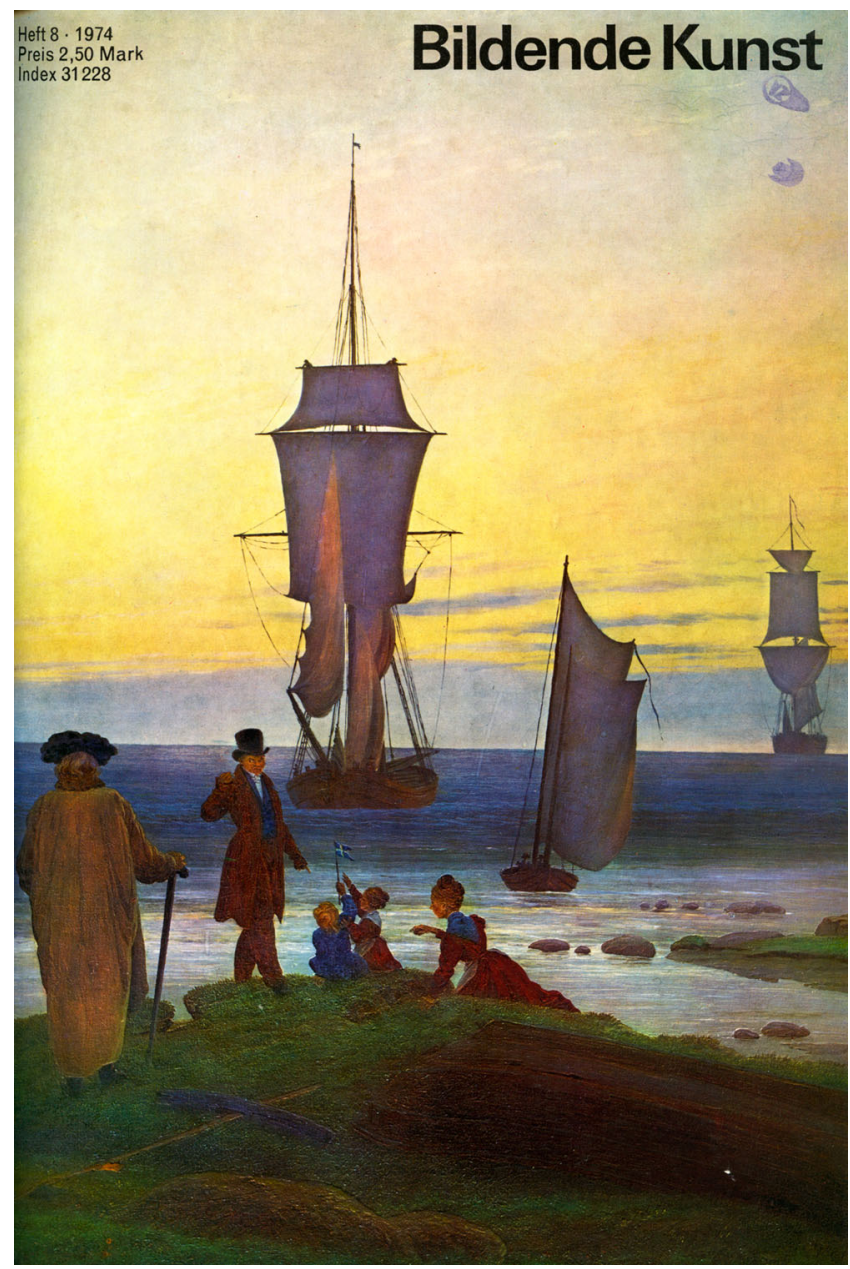

Fig. 3. Cover of the journal Bildende Kunst, no. 8, 1974, with a reproduction of Caspar David Friedrich's painting The Stages of Life, I835. Photo from the author's archive.

landscapes under Socialism were seen, represented, perceived, and interpreted through paintings, a more general discussion of its representations seems necessary. Therefore, this essay is structured in the following way. Taking the comparison between Friedrich's and Mattheuer's works as starting point, I am going to discuss in the first part of this essay how depictions of landscapes in the GDR can be judged as "cultural images, pictorial ways of representing, structuring or symbolizing surroundings" of real, existing Socialism (Cosgrove and Daniels 1988, I). By analyzing the imagery of landscapes through painting and "by setting it in its historical context" (2), I show that every analysis of symbolic representations of landscape has to be relativized as phenomena of a specific given time 


\section{Größe und Grenze romantischer Kunst}

\section{Ausstellung zum 200. Geburtstag Caspar David Friedrichs in Dreśden} Von Joachim Uhlitzsch
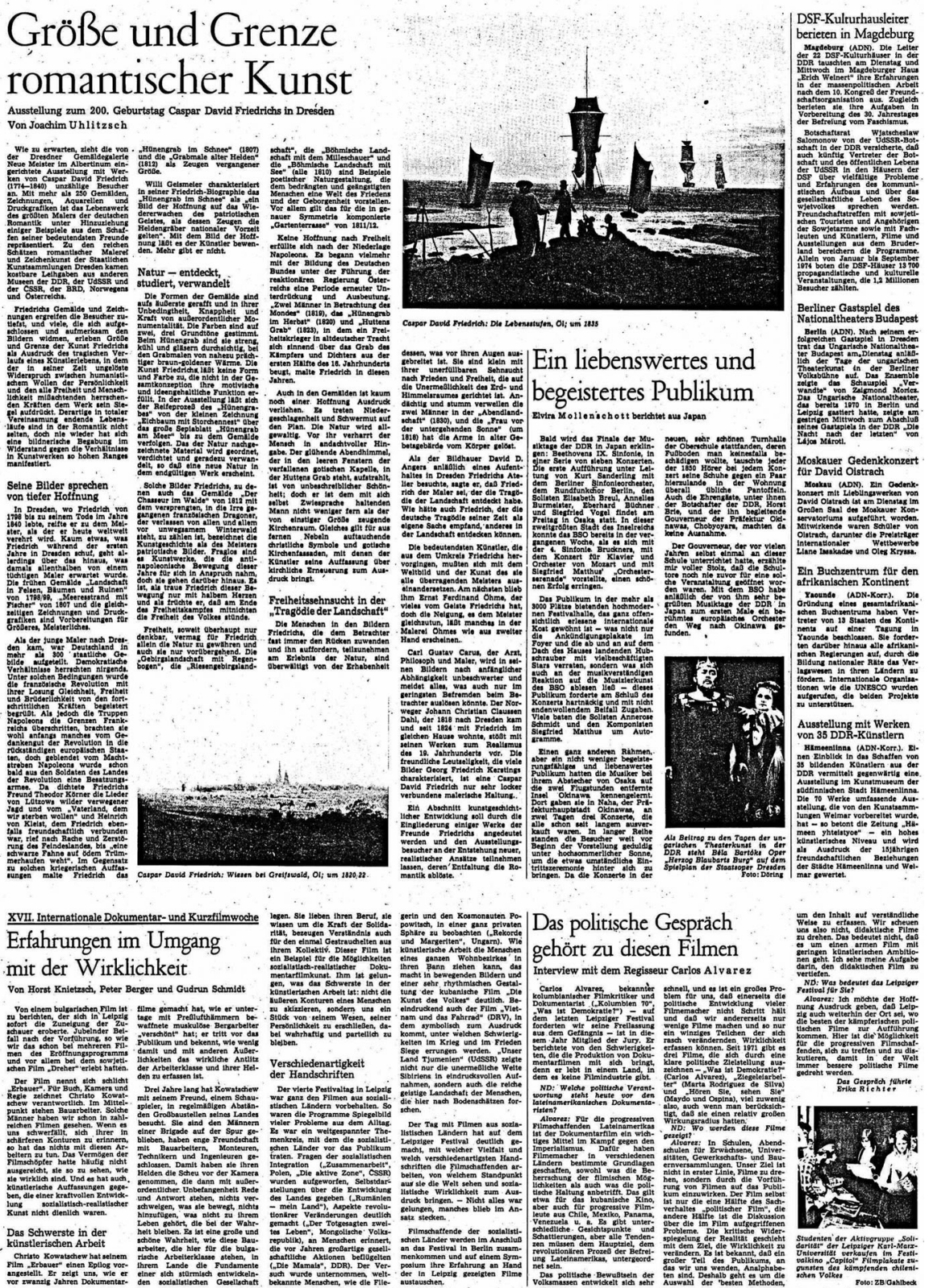

Fig. 4. Joachim Uhlitzsch, "Importance and Limitations of Romantic Art," on page 4 of Neues Deutschland, 28 November 1974. Photo from the author's archive. 


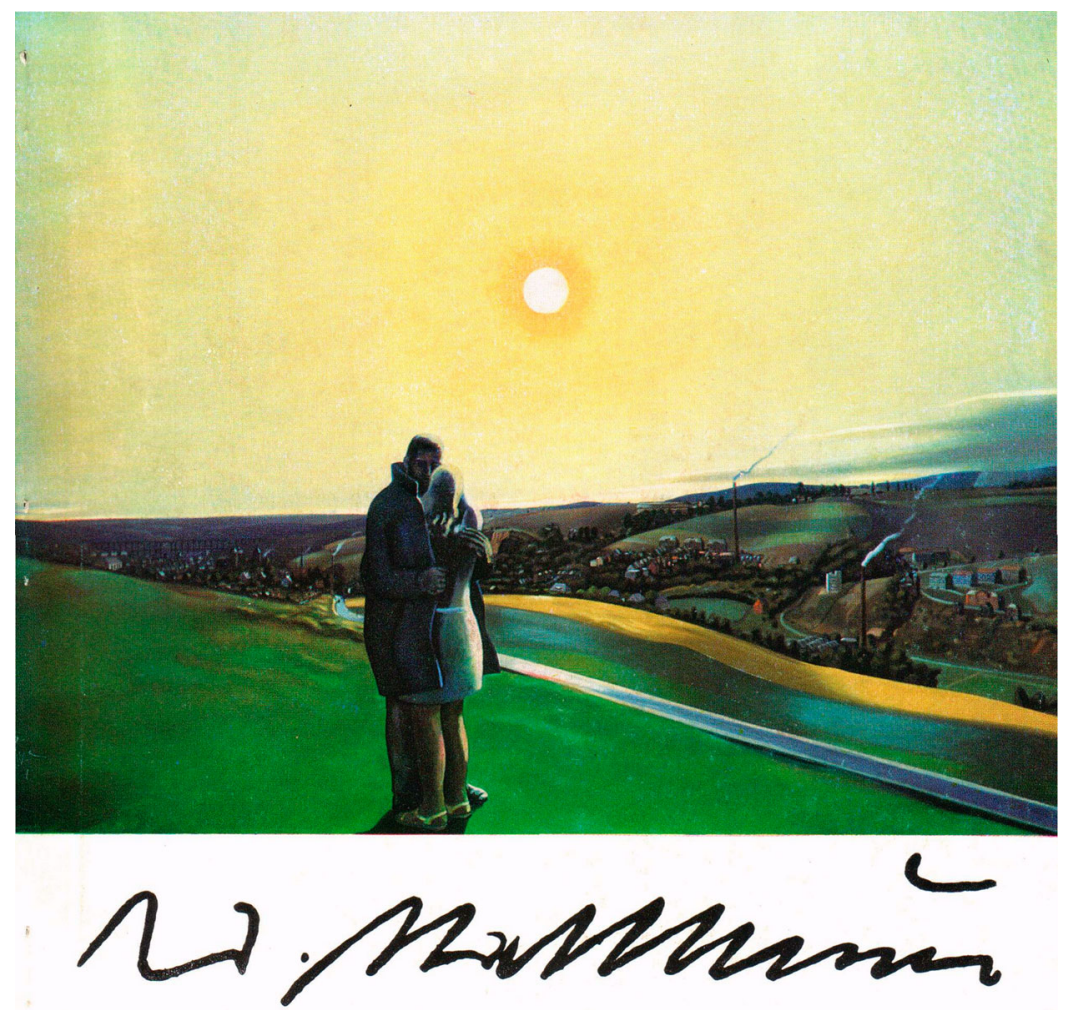

Fig. 5. Cover of the exhibition catalog Wolfgang Mattheuer, Dresden, 1974. Photo from the author's archive.

and place in history. Supporting an argument which has been brought into the debate by Simone Tippach-Schneider (2004, 2I), I argue that the "motif of landscape in the visual arts of the GDR was never an end in itself, but goes far beyond its object" and could also serve as a critical element in public discourse.

In the second part, I introduce briefly the history of landscape painting after 1945 in East Germany to link the reception of Friedrich's romantic art, Mattheuer's landscapes, and the ongoing debates on landscape art in the GDR. Here, I analyze and reread Bernhard Kretzschmar's (1889-1972) iconic first Socialist landscape painting View of Eisenhüttenstadt (1955-8) as mirror image to Friedrich's and Mattheuer's meaningful landscapes.

In the third and last part of my essay, I show that Mattheuer's artworks are not only romantic-masked critiques on environmental issues, as has been suggested (Hertel 20I4, II-2), but also unique contributions to a renewal of Socialist art through the genre of landscape. I end my essay with a summary of and outlook 
on the concept of Sotzromantizm, exemplified here by landscape paintings of the GDR.

\section{Friedrich and Mattheuer: The Concept of Sotzromantizm as Actualization and Historicization}

The historicization and actualization of the romantic era-exemplified by the 1974 exhibitions and conferences on Friedrich and Mattheuer-are directly linked to the genre of landscape painting with the changing image of man, nature, and society in Socialist ideology and in visual culture and with theoretical discourses on the role of landscape under Socialism (Kühne 1985, 4I). Here, the concept of Sotzromantizm provides an innovative, flexible model to contextualize historically anachronistic or contradictory phenomena, even in the visual arts of the GDR. Since this concept is connected with the development of historicization and actualization of romantic narratives, taking the positive reception of Friedrich's work and Mattheuer's breakthrough as landscape painter can serve as a starting point to explore the paradoxical situation of the emergence of romantic-inspired art in the GDR of the early I970s.

Mattheuer's genuine contribution to Sotzromantizm can be seen as both a critique and a renewal of late Socialist culture in the GDR. Mattheuer's success and Friedrich's return as a role model for Socialist art are two outcomes of the same process, which can be described as the historicization and actualization of romanticism. Historicization incorporates the art of the romantic era around I80o into a positive prehistory of the Socialist visual arts, offering a less dogmatic and more objectified approach to the past. This is linked with the profanation of Friedrich's spiritual landscapes (Busch 200I, 52I). Actualization, on the other hand, means that contemporary artists in the GDR like Mattheuer demonstrated that the language of the romantic movement-as well as ideas linked with it—could be used as an aesthetic, stylistic, and formal toolbox for Socialist art. So Mattheuer not only invented a genuine expression of Socialist landscapes based on Friedrich's romantic landscapes but also managed to meet the expectations of an audience whose members were able and willing to decipher his art as a representation of their own daily lives, attitudes, values, desires, and issues in actually existing late Socialism.

Since the 196os, shifts in the judgment of romanticism took place in the intellectual and aesthetical landscapes of the GDR, not just in the visual arts but also in philosophy and aesthetic theory. I am especially referring to Lothar Kühne's (1938-85) important essay "House and Landscape-An Outline of the Communist Culture of the Social Space" of 1974-exactly the year in which Friedrich and Mattheuer were displayed and discussed in the GDR.

The point that Mattheuer was the inheritor of Friedrich-as an actualizer of romanticism for the purpose of the evolution of Socialist art-has been put forward since the I970s and was invented by East German art historians (figs. 6-7). First, 


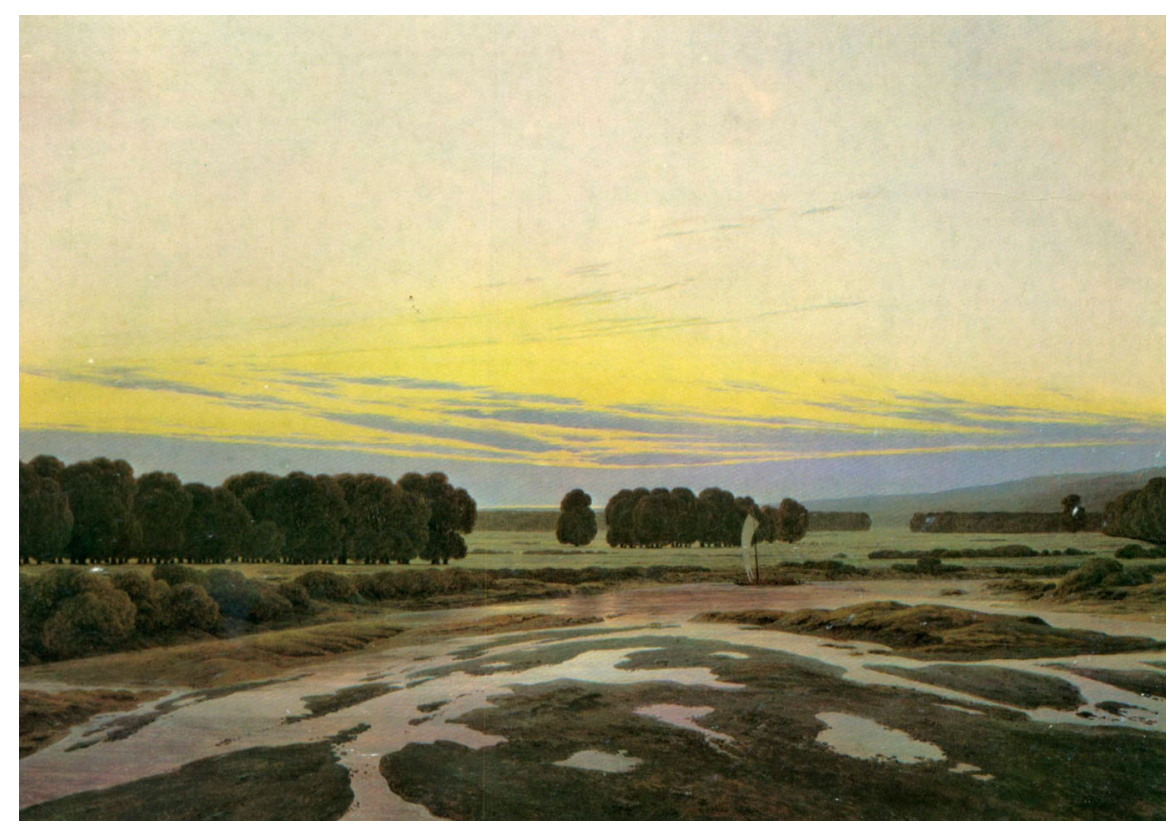

Fig. 6. Caspar David Friedrich, The "Große Gehege" near Dresden, circa 1832, oil on canvas, Stately Art Collections Dresden, Gallery New Masters, Dresden, Germany, (c) Wikipedia Commons.

Dieter Gleisberg $(1970,227)$ mentioned in 1970 that Mattheuer's landscapes were "extended romantic spaces full of emotions." In his unpublished dissertation of 1978 entitled "On the Social Function of Contemporary Landscape Paintings in the GDR," Peter Romanus (1978, I04-IO) wrote that Mattheuer's romantic landscapes would mirror the aesthetic attitudes of modern man in the late I970s, symbolizing a distant relationship between human beings and nature. It was Heinz Schönemann (1988) who gave a detailed account of Mattheuer's formal and compositional orientation toward Friedrich in 1988. Even after German reunification in 1989-90, Mattheuer's romanticism remained the focus of art-historical research. Christoph Zuschlag (1999, 219-36) themed Mattheuer's landscape paintings as a historical source for interpreting cold war history. Two larger exhibitions in the past decade put Mattheuer's contribution to German landscape painting front and center. In 2002, Mattheuer confessed in an interview with Peter Iden (2006, 78) that he was "especially attracted by the landscape." Also, Gillen (2004, 74) touched upon the close connection between Friedrich's and Mattheuer's art as early as 2004. And later, in 2007, an exhibition exclusively on Mattheuer as landscape painter was shown in Leipzig. In the catalog, Jenns Howoldt (2007, 50-60) investigated the romantic roots of Mattheuer's art, and Eduard Beaucamp (2007, I4-26) focused on Mattheuer's attempt at a renewal of the romantic tradition of 


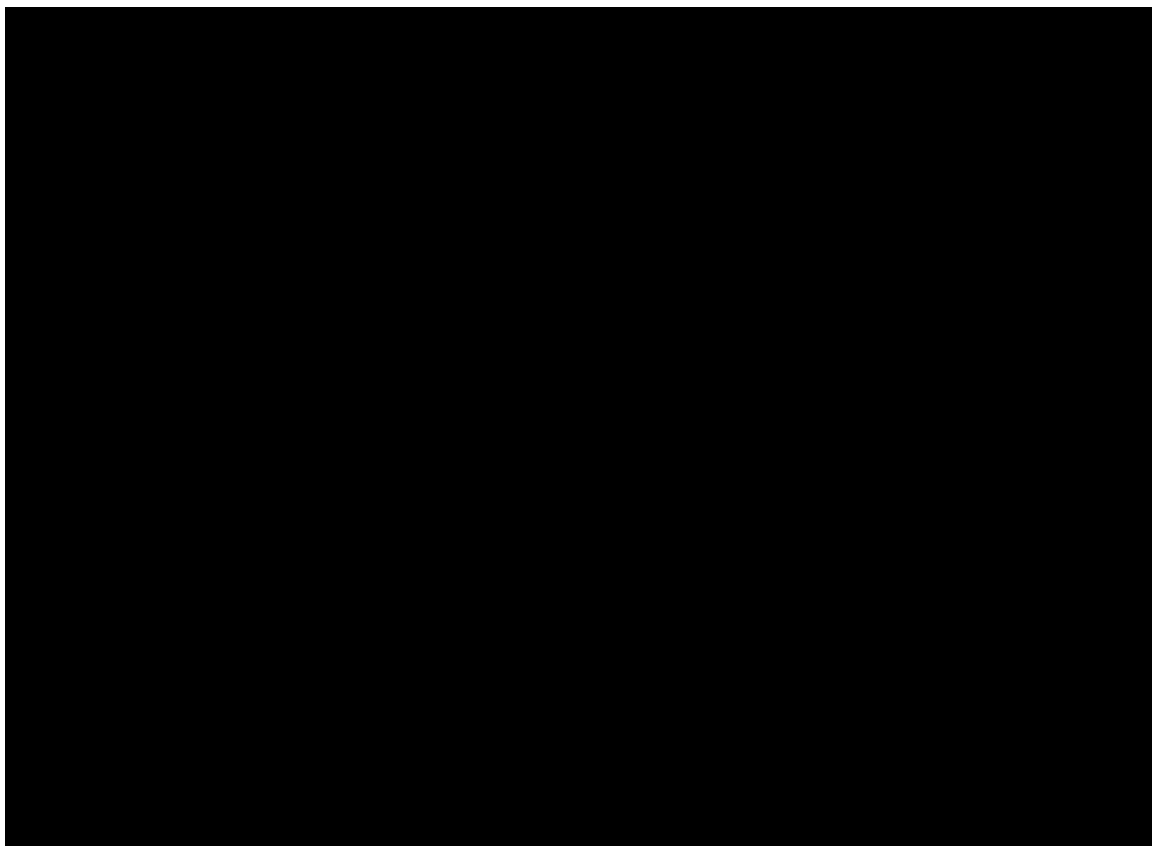

Fig. 7. Wolfgang Mattheuer, A Beautiful Evening, 1976, oil on canvas, Museum moderner Kunst Stiftung Ludwig Wien, Vienna, Austria. Photo from the author's archive. (C) 2016, VG Bild-Kunst, Bonn.

landscape as a carrier of meaning. As recently as 20I4, Anja Hertel (20I4, II-2) published her dissertation on Mattheuer's landscape as a carrier of political meaning, summarizing the state of research and adding to it a close reading of selected landscape paintings from I96I-83 as "political landscapes."

However, since the I960s, little has been done to explain the emergence of landscape painting in the visual arts of the GDR within the discourses on nature and landscape taking place at that time. Rather, Hertel's dissertation analyzes landscape in conventional ways grounded in the 1970s. For sure, this way of interpreting Mattheuer's (2002) landscapes is very convincing and justified by his own accounts in his diaries of the I970s and I980s. However, this artist-centered approach tends to neglect both the historical and the intellectual background of Mattheuer's political landscapes.

\section{Approaches to Socialist Landscapes}

Before discussing Mattheuer's achievements in establishing a Socialist aesthetic critique on the appearance of landscape in the GDR, it is necessary to shed light on the ways in which landscapes of Socialism and their visual representations 


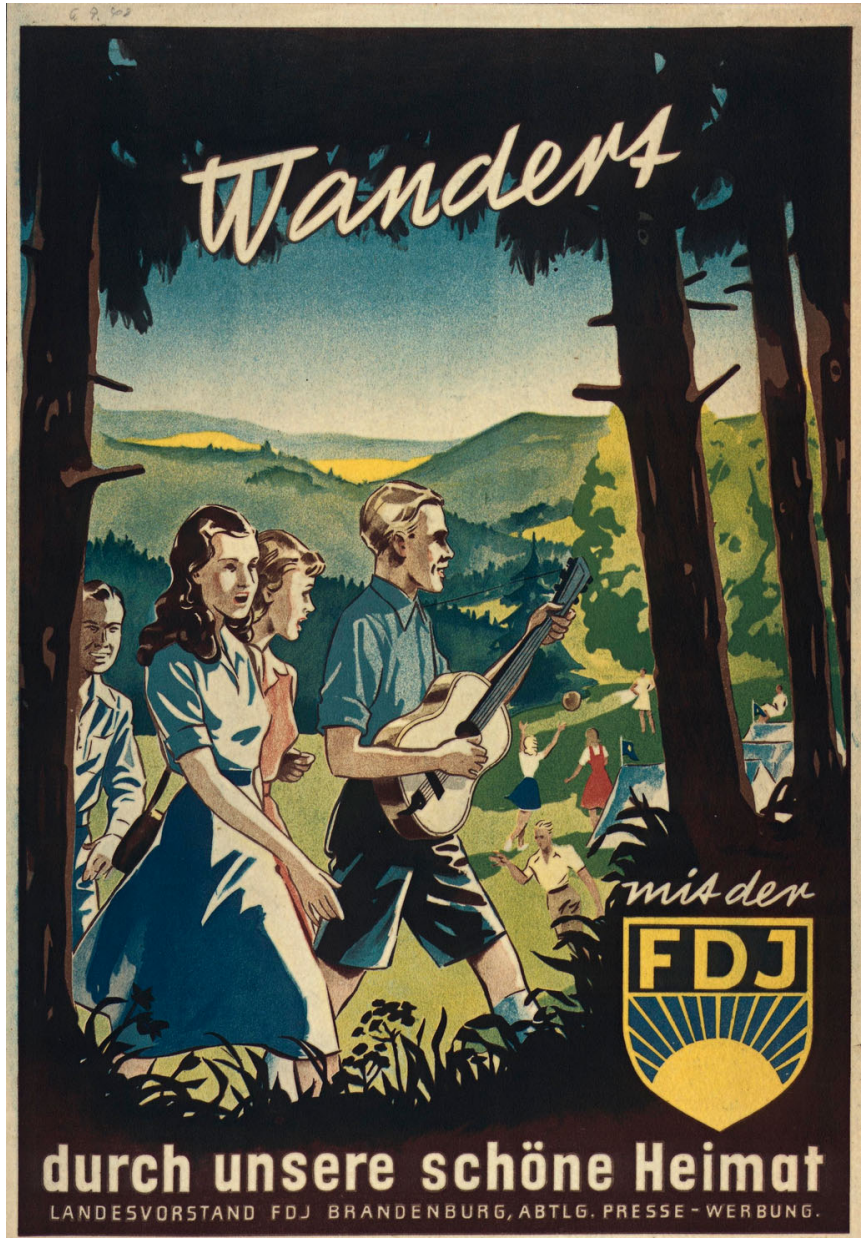

Fig. 8. Free German Youth, regional executive of Brandenburg, Migrate with the Free German Youth through Our Lovely Homeland, poster, 1948, Federal Archives, Berlin, Germany. (c) BArch, Plak Ioo-037-039/Werbe-Kobow.

can be theoretically approached. Basically, landscape was culturally significant and meaningful under Socialism. The depiction of landscapes or territories, famous sceneries and outlooks in movies, photographs, poems, graphics, murals, and paintings in the GDR always meant something more than just a topographical reflection of the very landscape; it referred to something outside the visual or literary representation (figs. 8-9). Wolfgang Emmerich (1996, 196-7, 374-9) has pointed out that literary descriptions and representations of landscape have played an important role and were seen by contemporaries as more than reflections of actually existing landscapes. 


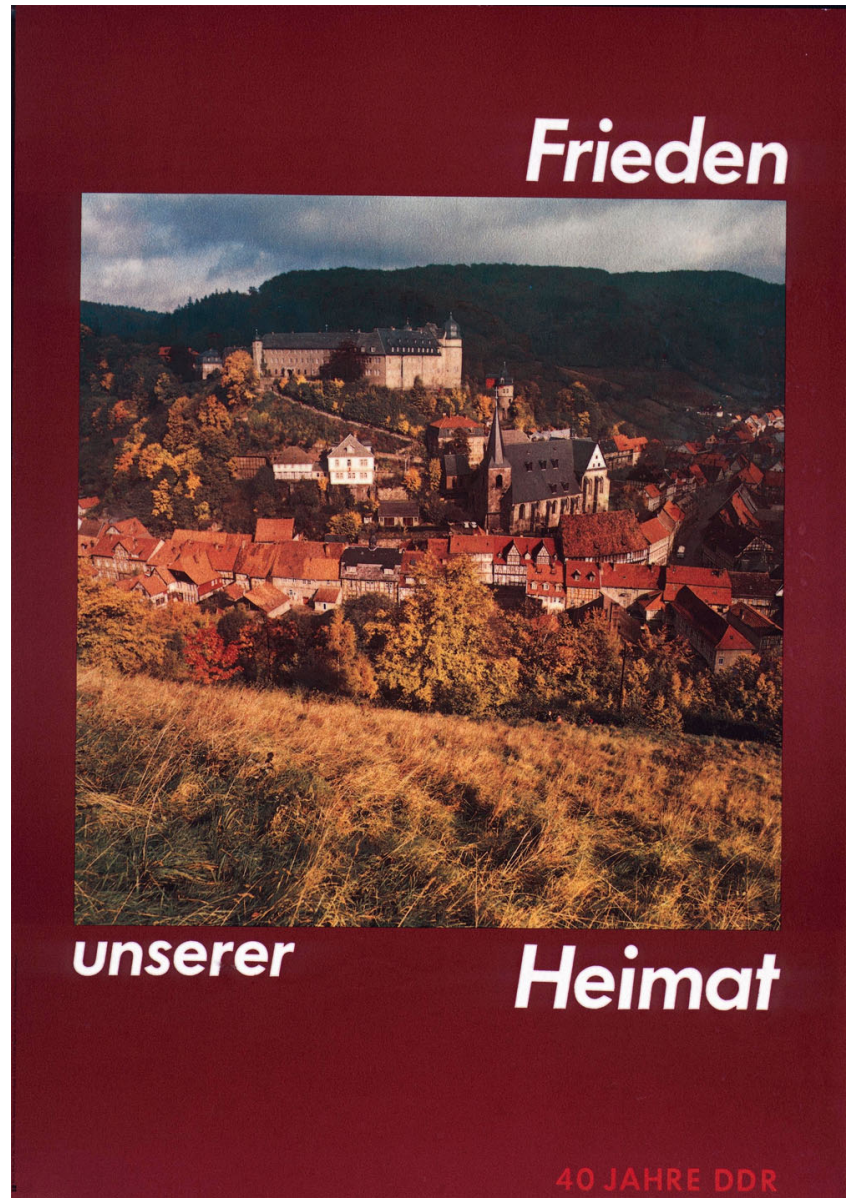

Fig. 9. Peace to Our Homeland, poster, 1989, Federal Archives, Berlin, Germany. (C) BArch, Plak I02-002-040/Horst Wendt.

The attempt of Socialist cultural politics after 1945 to occupy and resignify former aristocratic mansions in the East German countryside can be seen as an example of the ideological importance of the concept of landscape in a broader sense. Not only were palaces refurnished for new functions like "culture houses" (Kulturhause), hospitals, Kindergarten, or offices but also the gardens and parks of the palaces were redesigned and reused for social, public, or political activities as new Socialist greens (fig. IO). In other cases, parks were completely redesigned and opened as, for instance, the Island of the Youth (Berlin 1949) and the Island of Friendship (Potsdam I95I-74), Pioneer's Park (Berlin 1950-I) or as the First Horticultural Exposition of Socialist Countries (Erfurt; see fig. II). ${ }^{2}$ All of them were

2. For more on Erfurt, see Vagt (2013). 


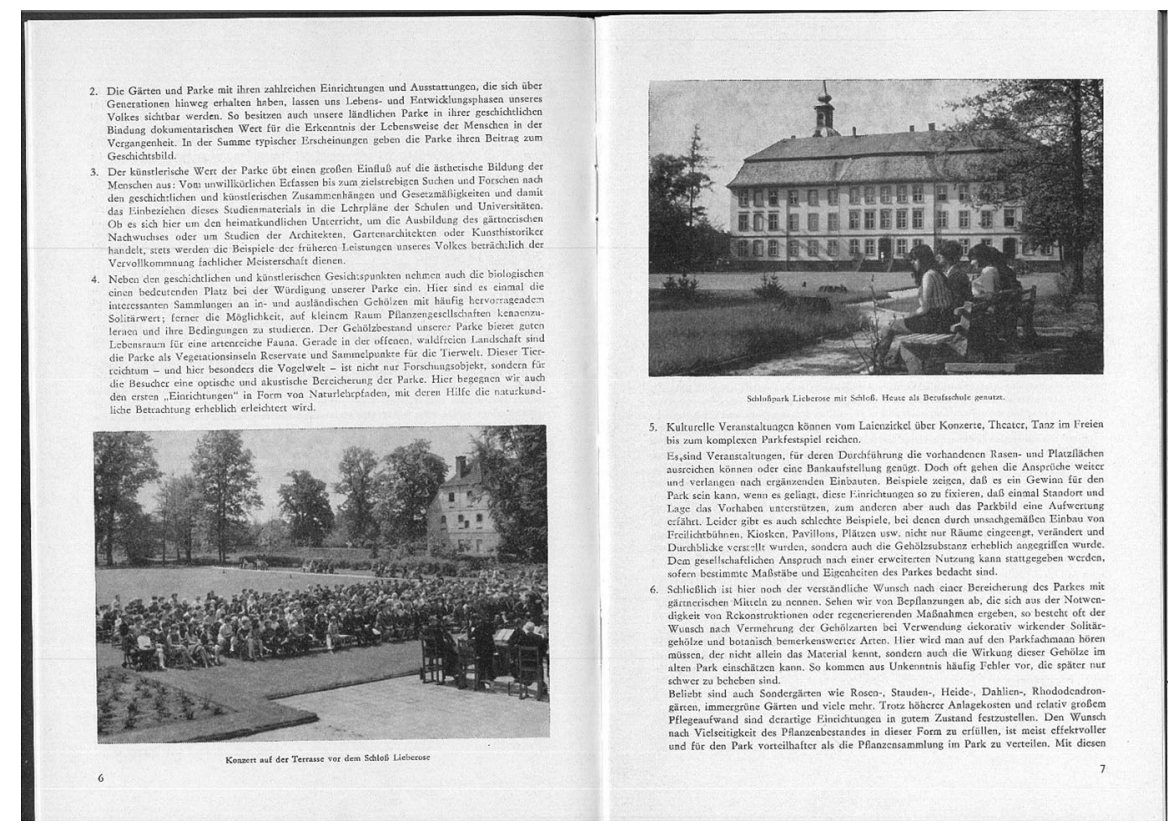

Fig. Io. Lieberose Palace and Garden, pages 6-7 of the book Maintenance of Rural and Historical Parks, ed. Cultural Association of the GDR (1972). Photo from the author's archive.

assigned as Socialist spaces and were deeply connected to the concept of manmade landscape, of "second nature," as important spaces of the Socialist humanization of society. ${ }^{3}$

The opinion that environment, whether natural nature or second nature, has a distinct influence on man and society but is also shaped by man and society can also be found in the art debates of the time. For example, the state-edited Dictionary of the Arts (Lexikon der Kunst), a long-term project of the I970s, dealt not only with genres, techniques, materials, and artists but also with aesthetic concepts of Socialist culture. It is no wonder that it also contained articles on "nature," "landscape," and "environment." These can provide insights in the ways that landscape and connected topics were judged by art historians and cultural scientists.

"Nature," as described in the article of the same name, is an "independently, outside-of-our-consciousness existing diverse set of organic and inorganic forms of existence and forms of movement" ("Natur" 1973, 502). Man has come from nature and arisen from it "through productive, spiritual and sensual appropriation for his purposes." It is important for our general topic to mention that the Dictionary of the Arts argues that nature and man are in a productive and connected

3. For similar attempts in the Soviet Union, see Kucher (2007). 


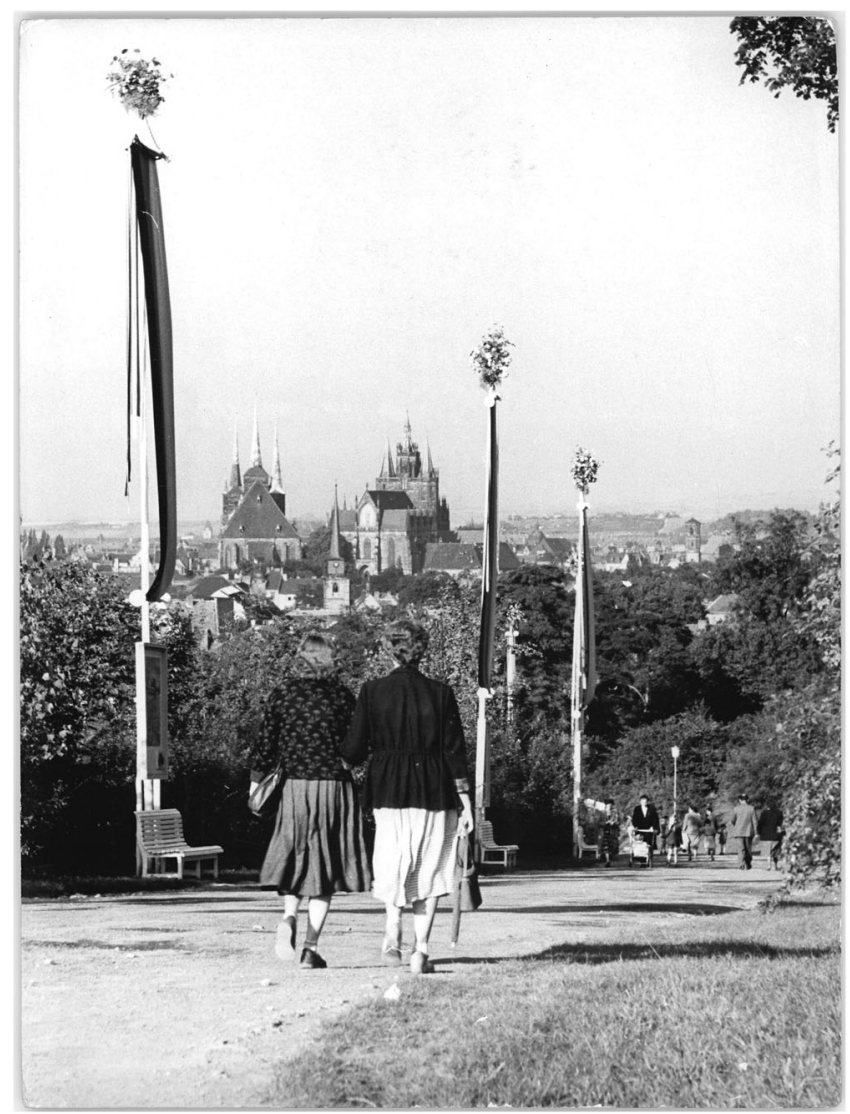

Fig. II. Horticultural Exposition of the GDR, View from the Exposition Grounds to Erfurt Cathedral, Erfurt, 1953, Federal Archives, Berlin, Germany. (C) BArch, Bild I83-32536-oooI/ Wittig.

interdependency wherein man has created a second nature through labor and productivity. This second nature is described as "artificial environment." Every landscape contains its manmade character as part of its second nature. The character of landscape as a manmade and man-shaping environment is represented, as this article suggests, in a "depiction of landscape" that "mirrors a specific relationship to nature" (503). Consequently, if the visual representation of nature tells us something about class and power structures, as well as about the economic status of a society, then the genre of landscape painting serves on one hand as the "human appropriation of nature through aesthetical, visual-artistic reproduction of untouched or man-designed natural environment." On the other hand, the genre should "clarify the relationship of man with nature, his thoughts and feelings and social views, through which the depiction of landscape gains emotionality 
and social-relevant content." The article makes clear that under these conditions a "value-neutral, artistic depiction of landscape" is not possible since visual representation always means something (Landschaft 1971, 850). Soviet landscape paintings, it continues, show "untouched nature as well as man-designed nature" and "teach with their works appreciation of nature-affirmative, sensuous Heimatliebe (loving of one's home)." This can also be traced in the landscape paintings of the GDR where especially the "depiction of nature which has been designed by the creativeness of man and the new cities" attracted artists (854).

As the cultural geographer Denis Cosgrove (quoted in Whyte 2002, 20-I) described in his 1994 essay "Landscape and Power," "Landscape is not an object but 'a way of seeing' rooted in ideology. It represents a way in which certain classes of people have signified themselves and their world through their imagined relationship with nature, and through which they have underlined and communicated their own social role and that of others with respect to external nature." The observation that landscapes are "a way of seeing" was also the starting point of Martin Warnke's (1995, I4) groundbreaking art-historical study, Political Landscape. He argued that "even the simplest topographical features are the result of political decisions." Even though Warnke was not interested in the political landscapes of Socialism or in the landscapes of the twentieth century, as Hertel has shown, his study still proves that the iconography of landscapes is a fruitful source for historical in-depth studies, even for Socialist examples.

Especially in the GDR of the I950s and 1960s, the role of Soviet imagery of landscape and nature as a borderless space of human labor and limitless pool of resources was chosen as the stylistic and content role model for the painters in the GDR. Visual representations of industrialized Soviet or East German landscapes were mirrored in philosophical discourses on nature. In those decades, from a philosophical viewpoint, nature/landscape was not seen as something to protect but as an "outer strange power" to be ruled (Moeck 2005, 152). The relationships between nature/landscape and economic and industrial needs was tilted toward economy, as can be traced in the paintings. This attitude toward landscape was shaped under Stalin in his 1938 book Dialectical and Historical Materialism (published in German in 195I) in which he denied that the transition of the geographical milieu has any determining influence on the development of a society (Löther 2007, 196). Later, in the 1960s, during the so-called "scientific-technical revolution," it was said-according to an anonymous article in the party newspaper Berliner Zeitung of September 1965-that the "qualitative transformations in the relationship between man and science and technique became the most important instrument in the appropriation and mastery of nature." ${ }^{4}$ Propaganda argued for the development of a modern, "rational" relationship to nature, which Klaus Gestwa (2010, II) has

4. See "Vor dem neunten Plenum des Zentralkomitees der SED: Menschen verändern die Weltund nicht Roboter (Zum Thema: Der Mensch in der technischen Revolution)," Berliner Zeitung, 2I April 1965, 3. 
described as an "energetic imperative to legitimate a progressive subjugation of nature."

Only in the mid-1970s, after changes in the political and economic structures of the GDR, did the party officially recognize the need for a more protective treatment of nature, as can be read in the Socialist Unity Party of Germany's (SED) program of 1976. Nature was described then "as inexhaustible source of life, of material wealth, of health, and of pleasure for the people," which must be "protected and rationally used" (Vaatz 1996, 860). The I970s marked the beginning of an environmental awareness among the people of the GDR since the damage to the environment was no longer contestable to the public (fig. I2). Consequently, not only can pragmatic support of ecological grassroots activities in the GDR be observed from the mid-1970s but also it is clear that thinkers and artists became more and more aware of the issue (fig. 13).

One example of this environmental awareness among Marxist intellectuals was Lothar Kühne. He developed within East German contexts a highly innovative and controversial argument reflecting upon the relationships of nature, landscape, and architecture under Socialism and Communism. Even though the work of Marxist critics in the GDR of the 1970s has caught the recent interest of political scientists and historians (see Amberger 20I4), Kühne's writings still need to be investigated. This also holds true for an art-historical analysis of the genre of landscape painting in the GDR and its relationship to environmental discussions.

First published in 1974 in the journal Weimarer Beiträge, Kühne's essay "House and Landscape" deals with the relevance of landscape as the "grounding moment of the material living conditions of mankind." Referring to Marx and Engels's German Ideology (1845-7), Kühne $(1985,9)$ argues that landscape is not a "simply given fact through nature" but that it represents an "objectified social relationship in nature." Every landscape therefore embodies "structures of social living conditions" and carries signs of human labor and its organization. Landscape is manmade and makes man at the same time. Landscapes encode the formation of the productive forces in the history of man since the earliest time in its specific signs. This development over centuries has been observed and analyzed by the Marxist-Leninist philosophy of dialectical materialism (36). For Kühne, landscape is not only a specific surface on earth with natural and artificial signs. In Socialism/ Communism, he argues, landscape is "the unity of social, micro-communal, and individual areas of space, which are summarized and interrelated in the house and the space of nature and the space of production" (39). The formation of Socialism and the future development of Communism will lead to new relationships between man and nature: "Those transformations include the aesthetical, practical-objective and practical-spatial relationship of man with nature" (30). He believes that only under Socialism can man and nature reach a harmonious state, while the capitalist system destroys natural resources and causes the alienation of man from nature (9). 


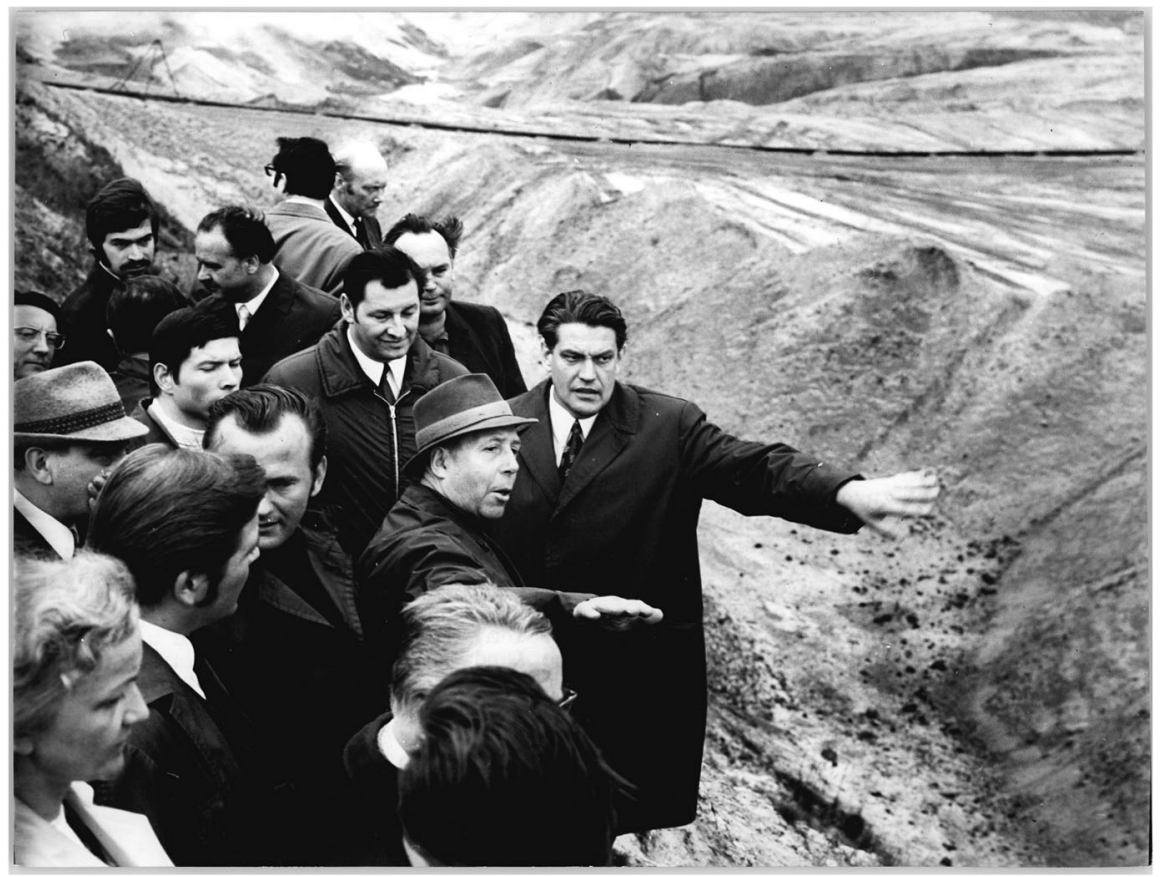

Fig. 12. Dr. Hans Reichelt, Minister for Environmental and Water Protection, visits a coal mine near Cottbus, I5 May 1972, Federal Archives, Berlin, Germany. (c) Bild I83L0515-0033/Werner Großmann.

That was virtually the official position of the SED, exemplified by Kurt Hager (1912-98), member of the central committee of the SED and responsible for ideology and propaganda, who in 1975 gave a talk at the Humboldt University of Berlin honoring the fiftieth anniversary of Friedrich Engels's 1925 Dialectic of Nature. In his speech, Hager $(1975,44)$ claimed that only Socialism and developing Communism are able to solve environmental problems because under Socialism "the character of Capitalism as limitless overexploitation of productive forces and reckless looting of nature" has been overcome. At the same time, the SED prevented the publication of critical empirical studies showing the factual status of the devastation of the GDR-ideological assumptions held as truths superimposed the factual power of reality (Amberger 20I4, 49). According to Amberger's study on ecological utopias in the GDR, Hager and the SED "predicted for future Communism the dialectic repeal of the contradiction between human productivity and nature. In the meantime, in actually existing Socialism or 'Dictatorship of Proletariat,' politics should work on the repeal of this contradiction" (47-8).

Despite the ideological specifications by Hager and others and despite the situation of the environment in the GDR at that time, Kühne argued with regard to the ongoing economic and industrial developments in Socialist countries that it must 


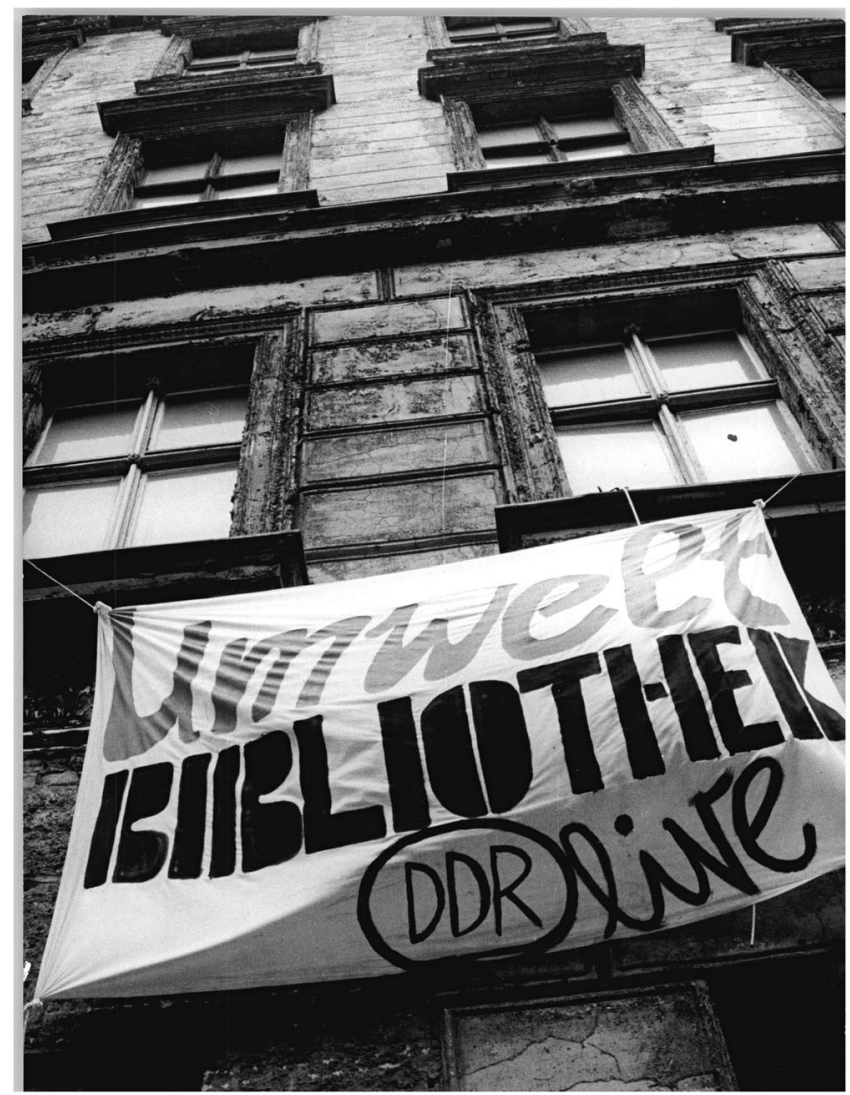

Fig. 13. Environmental Library, Berlin-Prenzlauer Berg, I7 January 1990, Federal Archives, Berlin, Germany. (C) Bild I83-I990-0II7-024/Klaus Oberst.

still be the ultimate aim of Socialism to establish a productive relationship between the working class and natural surroundings, including landscapes. Through labor, mankind appropriates nature and its forces-for example, coal or gas-and develops a harmonious state. But Kühne (1985, I0) also makes clear that even a Socialist society has its "limitations and problems of the design of the surroundings" that have to be addressed. Kühne's critique of an uncontrolled and destructive treatment of nature/landscape was based on Marx's I844 Economic-Philosophic Manuscripts, wherein he asserts that nature as earth is not only an object of labor for mankind but is "one side of the objective man, his inorganic body" (32). Under capitalism, nature and landscape become mainly a matter of utility and exploitation through the proletariat. So capitalism is alienating not only men from one another (and man from work and man from nature) but also man from the organic and inorganic parts of his entity. Instead, after establishing a Socialist society and economic structure, the working class can liberate nature as its 
inorganic body and could eventually build a harmonious relationship. Kühne's optimistic viewpoint with regard to the possibilities of a Socialist treatment of nature and landscape can be seen in the following quotation: "This is the point where the aesthetic as force of design of the practical living is not simply a form of the enforcement of the exchange-value standpoint but rather a constitutive moment of revolutionary and emancipating practice" (33). Not until the liberated individual in Socialism is aware of its own emancipation from capitalism and begins to "appropriate his own richness" can that individual "appropriate the richness embodied in the landscape" (42).

For Kühne as leftist, the "true" design of architecture and landscape based on the ideology of Marxism-Leninism was fundamental to a harmonious Communist relationship among people and between people and nature. The writings of Marx, Engels, and Lenin provide the tools and the inspiration for the Socialist/Communist reshaping of the landscape. For Kühne $(1985,4 \mathrm{I})$, "the Communist landscape" is the backdrop of and condition for the "world-historical realization of man." That is why he argued against the systematic and radical destruction of nature for the price of economic growth. Even though Kühne never saw himself as oppositional in a Western sense, this links his ideas with the ideas of other Marxist opposition thinkers in the GDR having environmental backgrounds, such as Rudolf Bahro (1935-97), Wolfgang Harich (1923-95), and Robert Havemann (1910-82). ${ }^{5}$ But since Kühne's Marxist philosophy is not precisely the topic here, I have only briefly pointed out some aspects of his thinking on nature, architecture, and landscape.

\section{The Importance of Socialist Landscape Paintings}

In the early 1950s, in the era between the crisis and consolidation of the new Socialist regime, ${ }^{6}$ East German art critics demanded paintings showing contemporary topics "mirroring the transformations in our social life and helping to realize its aims," as Traugott Stephanowitz $(1954,3)$ put it in 1954 . One year before, the artist and cultural politician Kurt Magritz (1953, 42) attacked the landscape paintings of the Third German Art Exhibition in Dresden because the visual "representation of people and the representation of landscape do not form an organic unit." While Ulbricht (1893-1973) as head of the party and leader of the state claimed that the visual arts and landscape painting in particular had to "inspire the masses for the great tasks of the building of Socialism" and to "celebrate the triumph of man over the forces of nature" (Mansfeld 1953, 27), the artistic results in the genre of landscape painting "disappointed" the state ideals of the I950s. Instead of tending toward Soviet Socialist realism with its neo-impressionistic styles and genre-motifs, the German tradition of nineteenth-century landscape

5. See Amberger (2014).

6. See Scholz $(2009,268)$ and Malycha and Winters (2009, I03). 
became the focus of artists and historians searching for the possible roots of a new landscape art under Socialism. With regard to the problematic of Marxist-Leninist ideology (Lukács 1980), this led to the rediscovery of the romantic art of Friedrich, Ludwig Richter (1803-84), and Moritz von Schwind (1804-7I). Even though these developments of the 1950s were only foreplay to the actualization and historicization of Sotzromantizm in the GDR in the 1970s, they show that the substantial qualities of nineteenth-century landscape imagery were also recognized under Stalinist cultural politics in East Germany.

That was, however, not a process starting in the 1950s, since also during the Nazi dictatorship of 1933-45, and even before in the Kaiserreich and in the Weimar Republic, the genre of German landscape painting was important for various reasons (Heinzelmann 1997, 218-9). In this case, the reception of the romantic era in the GDR can be seen as historically continuous in Germany from around 1900. As in the important Jahrhundert-Ausstellung (centennial exhibition) of 1906 in Berlin-in which the romantic movement and especially works by Friedrich were rediscovered and used for nationalistic, anti-French, and anti-modern sentiments (Busch 200I, 519) - Socialist art history began again to rediscover and reinterpret Friedrich and his circle, but now in a Socialist manner. With respect to landscape paintings, Hermann Müller (1953, I3) explained in Bildende Kunst that the difference between romantic and Socialist landscapes lies in the Socialist paradigm that "the close bonding [of art] with the people's life and the people's motherland" creates "a sensual, comprehensive, and practical representation of landscape." Romantic artists of the early nineteenth century had instead tended to overemphasize the spiritual forces of nature, and they fled into fantasy and religion. Later on, this critique was kept but historicized. The spiritual quality was explained as a way for artists to express their disappointments about sociopolitical developments in Germany between the French Revolution of 1789 and the fight against Napoleon culminating in 1815-romantic art as a form of inner emigration.

After Stalin's death in 1953 and during a phase of cultural liberalization, the tradition of romantic landscape painting was again the topic of exhibitions and articles in the GDR. The most important example was the show German Landscape Painting I800-19I4 by the National Gallery in Berlin in 1957. In his review, a classic text of Socialist interpretation of landscape painting (Hertel 20I4, 60), Kuno Mittelstädt $(1953,30)$ discusses the genre from an ideological perspective. His main arguments were that landscape paintings have served since the Renaissance as "mediation of ideology" and as "embodiment of a bourgeois sense of home and national identity." His review ends with the pathetic claim for a genuine Socialist way rooted in tradition to "develop a style of landscape painting that corresponds with the artistic principles of Socialist realism and that is a comprehensive and intensive expression of our life." The function of the visual representation of the landscape in Socialism is to "depict the landscape as a space in which the transformations of life and the building of a new society takes place." 
As I have shown, the position of Kühne $(1985,9)$ and others in relation to landscape was that it represented not only the "grounding moment of the material living conditions of mankind," as well as the ensemble of natural and artificial objects in an environment, but also the way that man has dealt with industry and labor in a specific area and how his "creativeness" shaped his natural surroundings. Even economic and historic layers were inherent to the construct of landscape, as the articles in the Dictionary of the Arts point out. And, very important, nature/landscape should not only be threatened from an exchange-value standpoint but also from an aesthetic point of view, as Kühne proclaimed (33). Here again is a conceptual link to the way that romantics in the nineteenth century saw the environment because they also believed in an inner, fragile relationship of man and nature next to an "objective," outer relationship. Despite Kühne's emphasis on the importance of landscape for Socialist society or art-historical manifestations that stressed the role and function of landscape painting for contemporary art, the visual representations and discursive layers in the GDR did not mirror that.

Rather, within the canon of genres, landscape painting was traditionally seen as low compared to historical painting (or "era image"), the supreme genre (Pracht I975, 282). Nevertheless, even landscape paintings had to contribute to the verifying of the future and to the building of a Socialist society in the GDR. Until the late I960s, the Socialist critique of the romantic movement-with its emotional-spiritual relationship to nature-hindered the debate by excluding examples of romantic landscapes that might have served as good examples for a patriotic and technically advanced representation of landscape in a Marxist sense. However, even though it was not possible to discuss romantic role models for Socialist art until the I970s, awareness of the central achievements of landscape paintings from around I80o as carriers of meaning never disappeared. A significant change in the position of the genre of landscape painting in the hierarchy of visual arts can be observed between the late 1940s and the I970s. This dynamism in hierarchy is also recognizable in the ways that art historians discussed the role, function, and style of landscape painting (Schulze I974, II).

One example of the changes of the I950s is Ullrich Kuhirt. In his essay "Man and Labor in a New Relationship," published in 1958, Kuhirt argues that, under Socialist conditions, man and labor have established a new relationship that should be visualized. For Kuhirt $(1958,232)$, the genre of landscape painting was an ideal type for "making the special qualities of Socialist labor noticeable and recognizable." According to him, the genre has to symbolize "the becoming of the Socialist building, the quality of liberated labor, the new, by degrees emerging beauty of manmade things." In a highly idealistic view of art, Kuhirt proclaims that "man and their machines are new, at the same time not disturbing but organically integrating elements of the landscape and overall their masters."

Ten years later, in 1968, Getraude Sumpf in Landschaft und Industrie (Landscape and Industry) reflected on the landscape paintings that had been shown in the 
Sixth German Art Exhibition in Dresden. For her, the depiction of the industrial landscape, as well as portrait and historical painting, "has the special quality to mirror the understanding of the world of modern man in Socialist society and his lifestyle" (Sumpf 1968a, 239). Landscape paintings with industrial elements like factories or construction sites, she continues, "are never simply a pictorial presentation but they are always embodying a piece of the creating and shaping man, our Socialist contemporary," which can be deciphered and read (242).

According to Warnke, collecting, exhibiting, and displaying painted landscapes have been common courtly practices of the symbolic and factual performance of power ever since the Middle Ages. By presenting the possessions and the richness of their countries in works of art, kings, leaders, and dictators proved their ambition of complete rule over their territories. Possessing a painted landscape nearly always meant possessing its real counterpart-or at least meant a claim of ownership of the real landscape. The dictatorial regimes of the twentieth century relied on those premodern beliefs of the power of landscape paintings. Portraits of Stalin "in the landscape" from the I940s visualize a "totalitarian idyll." Stalin's ambitions for universal power over man and nature are manifested as "visions of utopia" in industrialized landscape imagery in Soviet paintings (Morozov 2003, 82; see fig. I4).

While Stalin was often depicted in landscapes, Ulbricht was shown in genre scenes of agricultural reforms or as the inspirer of the construction of new Socialist cities (fig. 15). While scientific discourses on the genre had developed from the I960s in cultural politics, the hierarchy of the genres was again manifested in the old-fashioned canonical way that the GDR designed the interior of the People's Palace in Berlin as the central building of the state. Begun in 1972 and finished in 1976, it incorporated a series of forty-four landscape paintings by twelve artists in rooms that were used for political and social activities (Romanus 1978; see figs. 16-7). They were dedicated, as Romanus wrote, "to the beauty of our country, the achievements of the people, and the treasures of nature." Furthermore, they could "contribute to the aesthetical appropriation of our natural and social environment as they make the relationship of man to society, to his own and to his objectified forces in the landscape tangible" (Romanus 1976, 448). Here, we find exactly the "nature-affirmative, sensuous Heimatliebe" that was demanded from landscape paintings in the Dictionary of the Arts (Landschaft 1971, 854).

Paradoxically —and ironically at the same time-this setting can be tied back to baroque role models such as the Prussian palaces of the eighteenth century in Potsdam and Berlin, or early modern Saxonian courtly architecture in Dresden, as both incorporating and displaying landscape paintings of their state territories. But this historic-ideological diachronism of role models of absolutism was not questioned. Officially, the aristocratic mode of representation through and with landscape painting was seen as a symbol of the "diversity of the Republic with its landscape beauty and its people" (Kuhrmann 2006, II2-3). Instead of pointing out the obviously anachronistic early modern approach to landscape as power and possession speaking out from the series of paintings-a claim recited in 


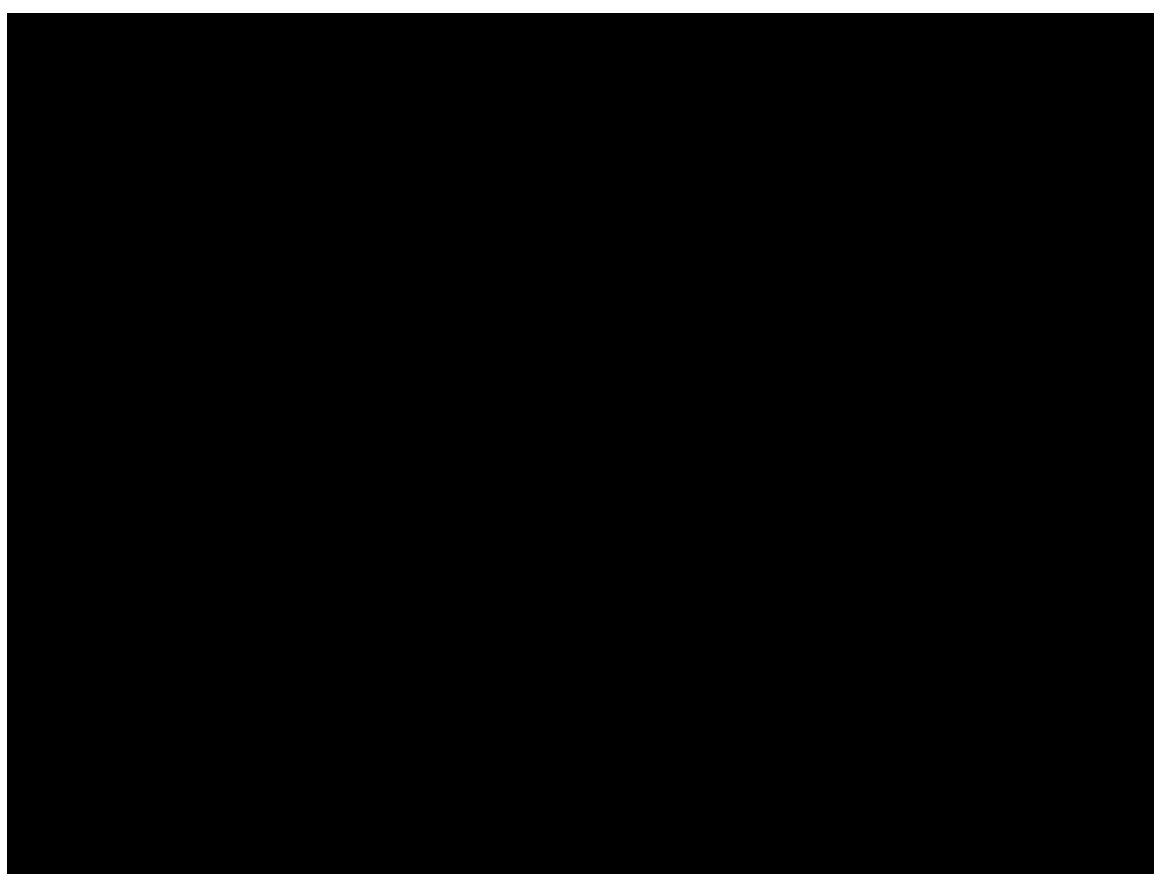

Fig. 14. Viktor Semenovič Ivanov, According to the Plan of Stalin We Will Change Nature! Poster, I949, Museum of Design Poster Collection, Zurich, Switzerland. (c) ZHdK.

artworks that early modern and baroque rulers also used for their political visual propaganda, shown here by the Socialist Party's aspiration to rule the whole country and its provinces-one argued from a class viewpoint when speaking about the artworks in the People's Palace.

In his thesis of 1978 written at the Academy of Social Sciences at the Central Committee of the SED, Romanus discussed the landscape sceneries in the People's Palace. For him, landscape paintings enable "the viewer's ability for a delightful encounter with artistically appropriated habitat." They would give "insights into different social relationships" because landscapes can be seen as "object and medium of social production, as space of communication and recreation of people, and as reference points of different emotional and aesthetic experiences of the personality" (Romanus 1978, IO). In his study, Romanus focused on the viewer of landscape paintings in his approaches. His background as social scientist becomes obvious. He argues that visual representations of landscapes could appeal to "the inner, spiritual world of people and their emotions" (64). Being a carrier of meaning and of epochal thoughts, landscapes might also express in their visuals "the ideal understanding of an era" (85). Thus, the "ideal 


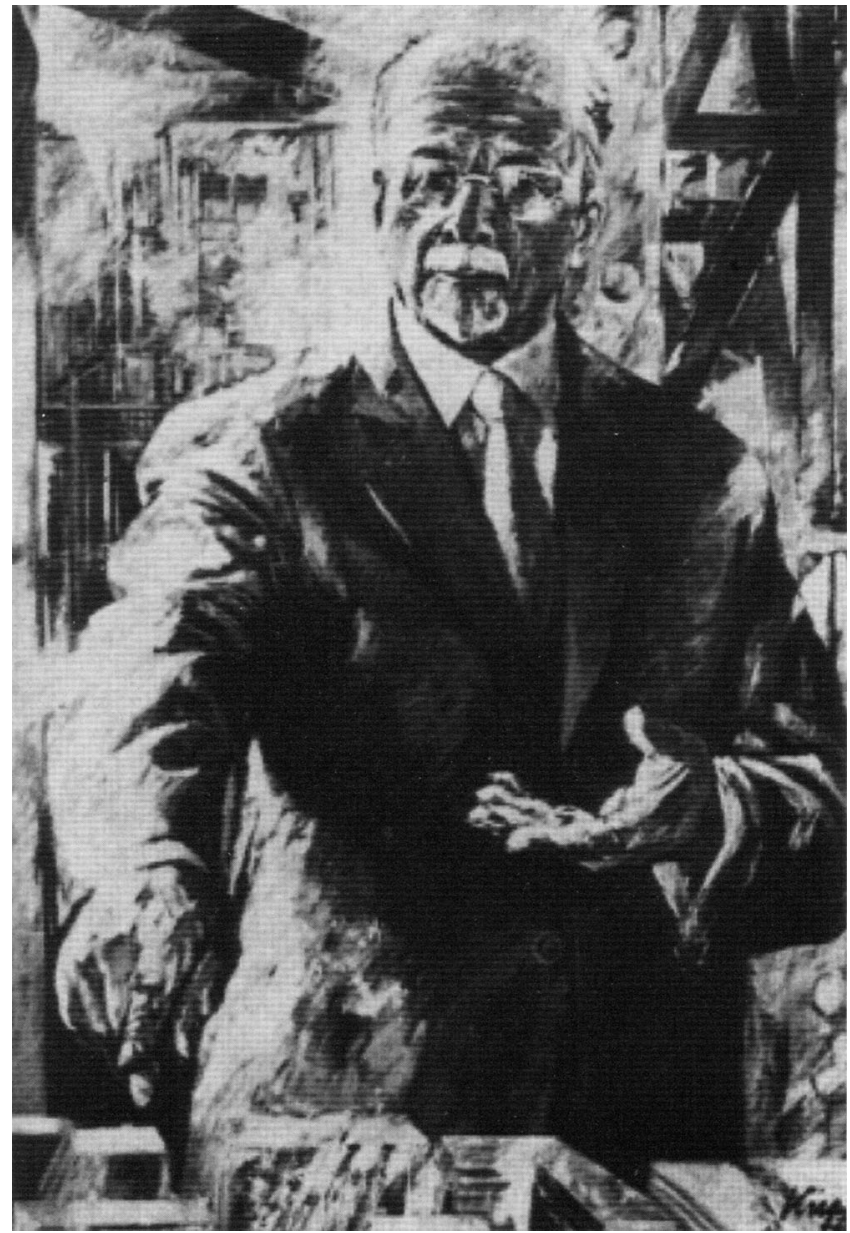

Fig. 15. Rolf Kiy, Portrait of the State Council of the German Democratic Republic, Walter Ulbricht, in Halle/Saale, 1970, oil on canvas. Photo from the author's archive.

understandings of an era" - the visual representation of thoughts in and with the landscape - are historically dynamic and change over time. Romanus also distinguished between landscape paintings in which the harmony of society, nature, and man is dominant; those landscapes in which an overall harmonious expression is shown but in a way embodying critical aspects; and finally, those landscapes in which "the critical judgment is the artist's main request" (I4). However, one more point seems of interest in the argument that the symbolic representation of landscape anticipates future developments. Romanus also wrote, "Landscape paintings as poetic designs of the future ... refer to the contrast between the contradictory reality and the poetic representation of harmonious relationships between society and nature" and aim to visualize these "as a desirable social ideal as an 


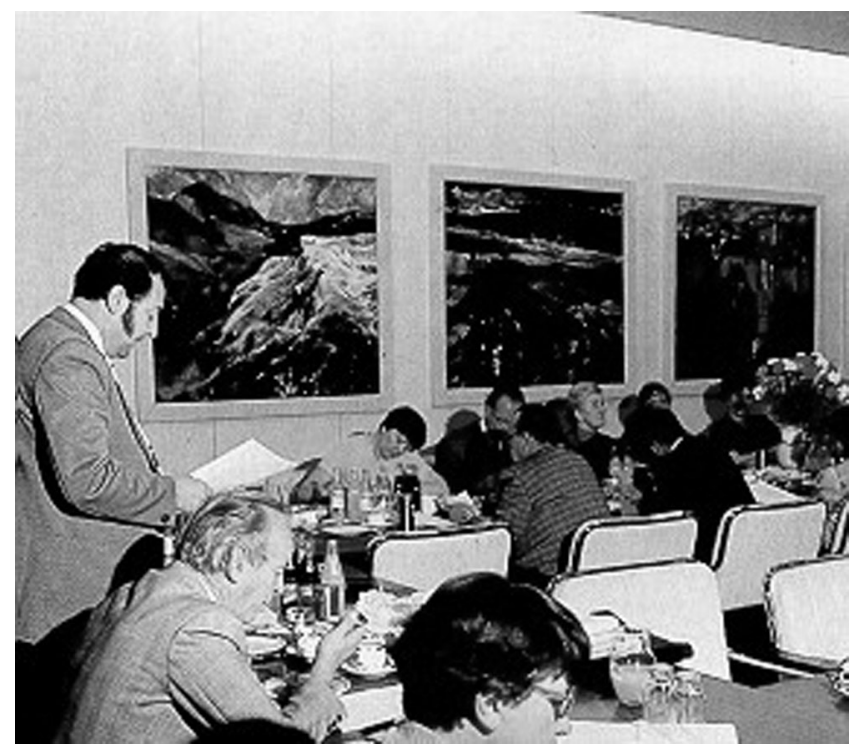

Fig. I6. Conference room at the People's Palace, Berlin, with landscape paintings by Harald Metzkes, I980s. Photo from the author's archive.

Fig. 17. Harald Metzkes, Lusatia Mountains, 1975, oil on canvas, Art Collection Lusatia, Senftenberg, Germany. (c) VG Bild-Kunst, Bonn 2016. 


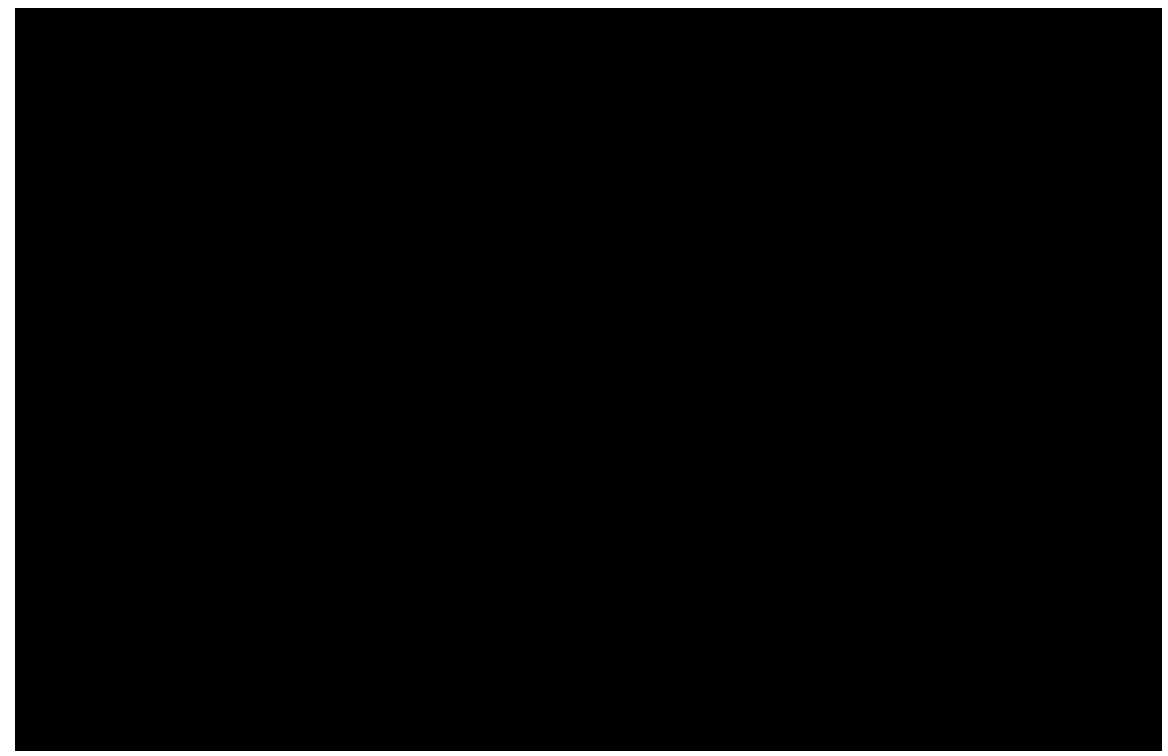

Fig. 18. Bernard Kretzschmar, View of Eisenhüttenstadt, 1955-8, oil on canvas, Museum for Young Art, Frankfurt/Oder, Germany. (c) VG Bild-Kunst, Bonn 2016.

historical feasible harmony" (IIO). That means that even Romanus's late-I970s study referred to an old topos in Socialist utopian thinking which was also envisioned by Marx: the repeal of all differences between man, nature, and society in Communism and the erection of a realm of freedom. For Romanus as a partisan scientist, the romantic movement and Friedrich's art were not worth researching as inspirational sources for contemporary landscape painting like they were for Bachmann (1976, II), the director of the State Art Collections of Dresden, as shown in the beginning of this essay.

\section{Kretzschmar's View of Eisenhüttenstadt as a Socialist Role Model for Landscape Painting in the GDR}

At least one painting of the mid-I950s seemed to fulfill perfectly the demands for a Socialist landscape art embodying an organic relationship of people, nature, and industry, inspiring its viewers to contribute to the building of Socialism and celebrating the nation's beauty and progress: Kretzschmar's iconic View of Eisenhüttenstadt (Romanus 1978, 89; see fig. I8). Kretzschmar received a commission from the Ministry of Culture of the GDR in 1955 to paint the "first Socialist city" of the country, bearing the name Stalinstadt. ${ }^{7}$ It has been widely celebrated as the first

7. "Stalin's Town," until I96I; later it became Eisenhüttenstadt, "Town of Steel Smelting." See Männel (1989, 60). 
Socialist landscape painting, as a major step toward the "socialization" of the romantic tradition in East Germany (Kuhirt 1958, 227; see fig. 19), and as a symbol for the triumph of contemporary art over the bourgeois art of the past.

Kretzschmar's masterpiece belongs in a very long tradition of panoramic views executed by Dresden-based artists since the eighteenth century. It unifies older elements of an aristocratic view over the territory, the early modern element of staffage figures in the foreground, as well as a restrained impressionist style. ${ }^{8}$ Stylistically and compositionally, Kretzschmar painted a very anachronistic image for a modern Socialist role model of the 1950s, not following the Stalinist aesthetics of that decade but relying on naturalism in monumental and pathetical forms. However, its content and message were seen as contemporary and even utopian (Kuhirt 1958, 232; Schmidt 1970, 8).

By implementing the panoramic view of the newly founded industrial plant of Eisenhüttenstadt-described in 1963 by an anonymous journalist of the London Times as a "town of young blood and iron" in a landscape of "poverty and barrenness ... a desert" ("Town of Young Blood and Iron" 1963; see fig. 20)—and its settlement into a sunny, summery atmosphere under a clear blue sky, the artist created a utopian image of a striking Marxist vision, reminding its viewer of the repeal of all differences not only between classes and men but also between town and country, human society and the natural environment. ${ }^{9}$ In his landscape, Kretzschmar celebrated the construction of Eisenhüttenstadt as a symbol for the construction of Socialism in the GDR and as a milestone toward the realization of the Marxist utopia. ${ }^{\text {IO }}$ The visionary features of Kretzschmar's painting and the ideological implementation of landscape appears even stronger when comparing the discourse around the art work with literary reports and newspaper articles of the late I950s on Eisenhüttenstadt. It becomes clear that reports and photographs of the new city are not simple, factual descriptions. Media was creating a specific image of Eisenhüttenstadt, "the town of young blood and iron," as a materialized Socialist miracle, as a kind of superhuman achievement in the East German province. Authors, photographers, and visual artists like Kretzschmar-especially when describing the geographic situation of the city-emphasized that the workers of the GDR have created "a place of a new, a Socialist culture" where "only sand and sparse pines were found before" (G. and R. 1953, 4; see fig. 2I). ${ }^{\text {II }}$ No other viewpoint of the city was better to see and understand visually the transformation from desert into urbanity than standing on the top of a hill in the south of the city ("Diehloer Höhen," about 230 feet high) as many photographs and reporters had done before to get a full vista of the city's

8. For Kretzschmar's biography see Dalbajewa and Dehmer (201I, 58-67).

9. For more on Socialist environmental politics in Stalinstadt/Eisenhüttenstadt, see Scholz (2009, 310).

IO. For more on nature and Marxist utopia, see Seng and Saage (2012, II).

II. The cited article is signed only by initials; the actual names of the authors are unknown to the author. 


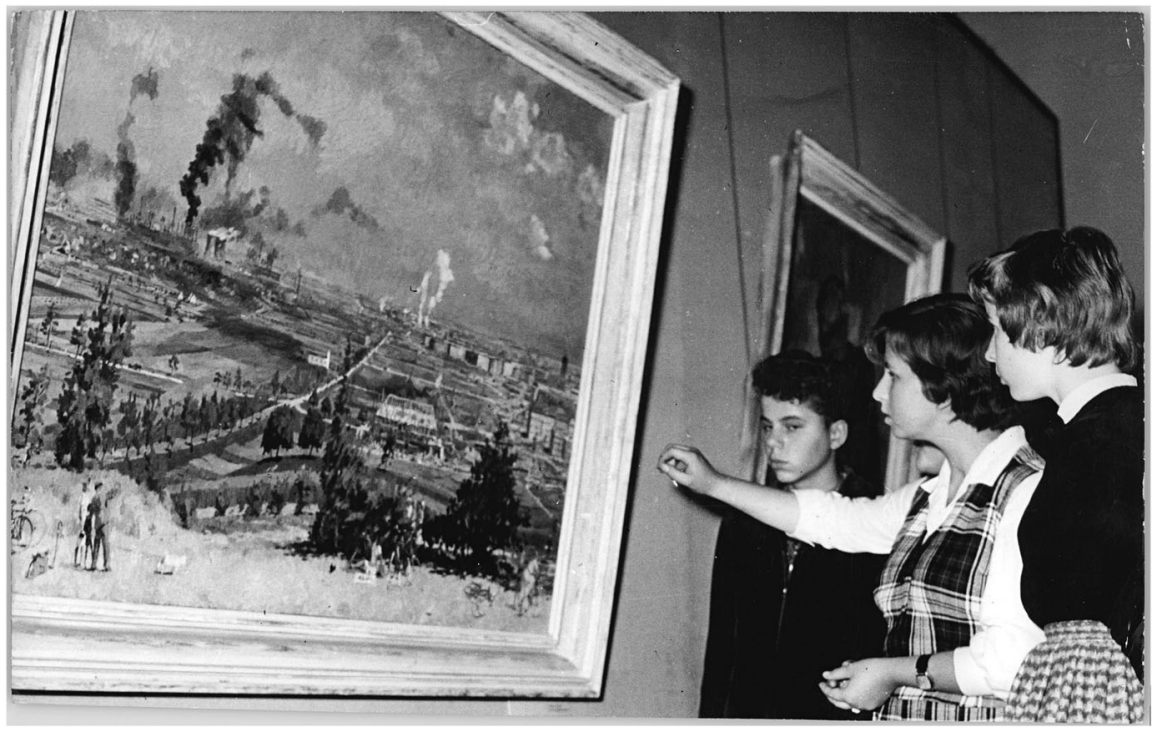

Fig. 19. Teenagers discussing Bernhard Kretzschmar's painting View of Eisenhüttenstadt, fourth German Art Exhibition, Dresden, 1958, Federal Archives, Berlin, Germany. (c) BArch Bild I83-59605-0002/Löwe.

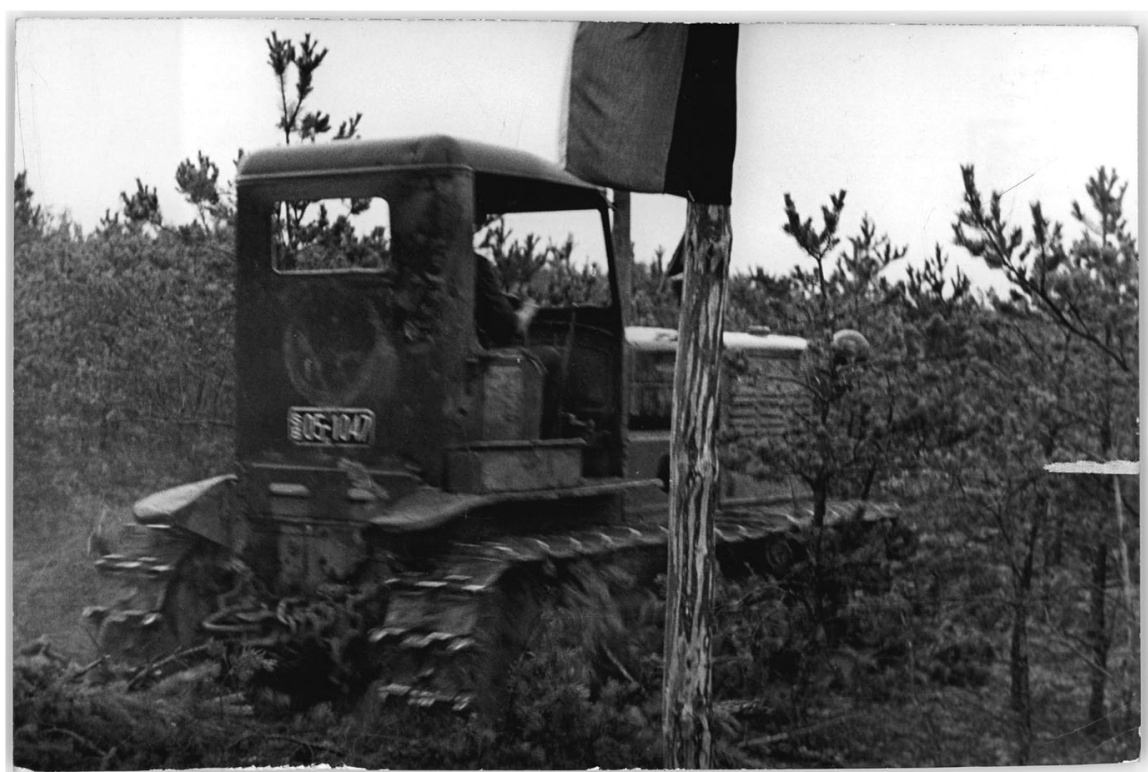

Fig. 20. Tractor clears the woods after the symbolic foundation ceremony of the new industrial town of Stalin-Town near Berlin, I8 August 1950, Federal Archives, Berlin, Germany. (C) BArch Bild ı83-Tooı9B/Hans-Günter Quaschinsky. 


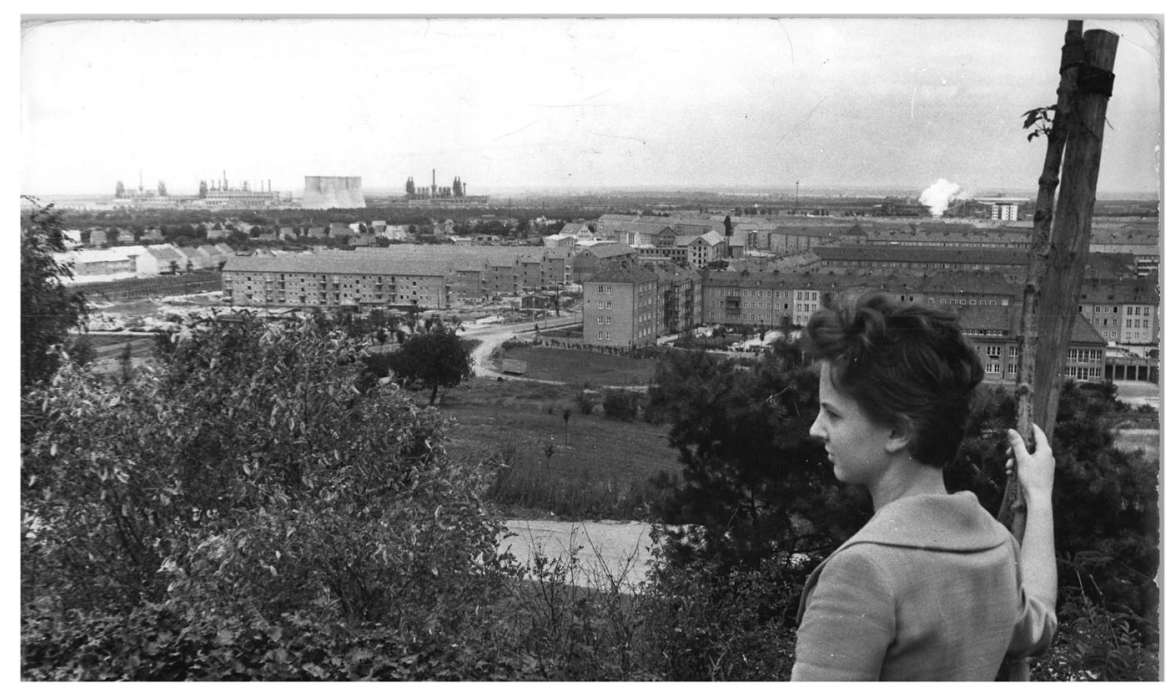

Fig. 2I. View of Eisenhüttenstadt (formerly Stalin-Town) from the hill "Diehloher Höhen," I4 August 1960, Federal Archives, Berlin, Germany. (c) BArch Bild I83-75484ooı8/Erich Zühlsdorf.

growth (fig. 22). ${ }^{\mathrm{I2}}$ With his icon of Eisenhüttenstadt, Kretzschmar also managed to oppose the sense of loss which was crucial for romantic landscape painting. He painted an optimistic answer as a symbol of creativeness and the power of the working class in the reconstruction of a Socialist state, even capable of building an entirely new factory and city in the 'desert'.

Kretzschmar integrated several groups of people in his panorama. They represent different forms of seeing and dealing with landscape. The people in this painting can be seen as carriers of meaning which invite the viewer to appreciate the "scope and meaning of the things happening in the scenery" (Schmidt 1970, 25). On the very left of the picture, the painter included a family of three, the father showing his son the scenery. One could interpret this family as symbolic representation of the old and new generations within GDR-Socialism. The elder father and mother belong to the founding generation that teaches the new generation about the heritage and the achievements of the state. The family is representing a moral and historical approach to landscape as, according to Kühne $(1985,39)$, "the unity of social, micro-communal, and individual areas of space, which are summarized and interrelated in the house and the space of nature and the space of production."

As Warnke (I995, II5) has shown in his book Political Landscape, "landscape motifs can repeatedly be invested with religious or moral significance," which is here also suggested for Kretzschmar's painting. In the mid-foreground, a young couple rests

I2. See Horlamus (1963, I2), Häsler (1966, 5), and "Auf du und du mit Stalinstadt," Berliner Zeitung, I6 August 1960, 3. 


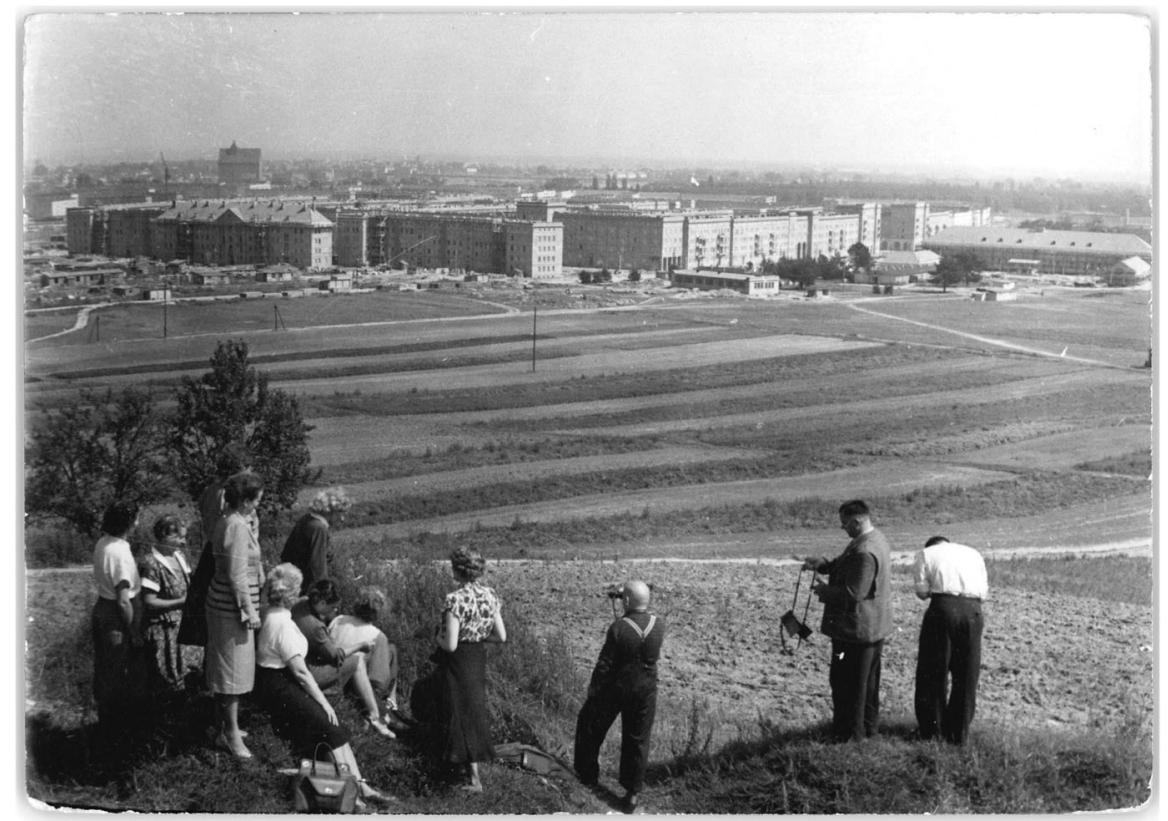

Fig. 22. Tourists regard Stalin-Town from a nearby hill, 2I August 1954, Federal Archives, Berlin, Germany. (c) BArch Bild I83-26oI2-oooI/Horst Sturm.

in the shadows of vegetation. Their view on the landscape must be very limited since they are sitting behind bushes. They are concentrating to one another and represent therefore a lyrical, "romantic" approach to landscape-as romantic refuge for emotions and feelings. Just behind the couple, a group of flaneurs is coming up the hill, showing another approach to landscape as vital scenery for sport and free-time. The same holds true for a pair of cyclists in the right foreground. Lovers, walkers, and cyclists are depicted by Kretzschmar as typical representations of a contemporary approach to landscape by inhabitants of cities. For them, landscape is not only a place of aesthetic contemplation or a carrier of moral meanings but also a more or less neutral space for pragmatic use.

The counterpart of the ideological approach to landscape which is symbolized by the family on the left is a self-portrait of Kretzschmar who is shown as a reddressed figure in the far right mid-ground. Recalling Friedrich's romantic use of the so-called Rückenfigur - which is shown with the back to the viewer-he is showing himself in the actual process of painting on an easel. However, he is not only symbolizing the authenticity of the painting as a true panorama of Eisenhüttenstadt, but also is representing a third approach to the landscape-in addition to the moral-historic and the pragmatic approach - that is the aestheticizing contemplation of the landscape rooted in the romantic era and manifested especially in Friedrich's landscape paintings. While Friedrich and others around 
I800 were barely represented as self-portraits in their landscapes, Kretzschmar situates himself within it as creator of the image and as element of the landscape at the same time. A parallel interpretation of this landscape goes that Kretschmar's painting is both a topographically accurate visual representation of the city and area of Eisenhüttenstadt and an allegory of different forms for how to approach a landscape under Socialism. Like the moral (family) and pragmatic approach (hikers, cyclists, lovers), also the aesthetic approach (painter) leads to the painted anticipation of a harmonious relationship between man and nature/landscape, a vision of the coexistence of the needs of human society under Socialism with the surrounding nature.

Kretzschmar's work was seen as "utopian" by some authors in the GDR because it anticipated an ideal status which had not yet been reached and which was a projection of hopes for a better Socialist future. Underlining the impression of a tranquil and peaceful interrelation of man and nature in Kretzschmar's panorama, he showed the steel factory as well as the urban structures as if they were organic parts of this industrialized landscape, not showing any of the negative aspects of its transformation in the last couple of years. The power station, the steel factory, blast furnaces, housing, construction sites, and the streets geometrizing the landscape do appear "naturalized" rather than "artificial" in this environment. The manly geometrization of space-recognizable in the alley running from the left to the center of the painting and the division of the mid-ground in parcels of land-appears ordered and clear. The color of the walls of the housing site on the right has the same color as the earth around it and becomes therefore a part of the ground. The naturalization of artificial, man-made objects in the landscape through aestheticization also becomes evident when comparing Kretzschmar's clouds of smoke from the factories with the "natural" clouds-they are hard to distinguish because of the same shared color and form. In his painting, no element of alienation of man and nature is recognizable. Instead, they are shown in a perfect, organic harmony, the repeal of all differences as Marx prophesized in Communism. In his personal utopian vision of Eisenhüttenstadt as a symbol and allegory for the progress in Socialism and the building of a new and better society, man has transformed nature into a Communist landscape without violating it. Schmidt had already emphasized this interpretation in the early 1970s. Regarding Kretzschmar's oeuvre, he wrote that landscape was for the painter "a social habitat, not just a beautiful sujet" (Schmidt 1970, 8). Schmidt also saw Kretzschmar's intention to anticipate a utopian vision of man and nature in his painting: "nature being disturbed in its rest already suggests its transformation into a human habitat, in which both will finally merge into a harmonious unity" (25). Especially when combining this work of art with the political propaganda around the new town, the utopian qualities of Kretzschmar's painting are obvious: "And Walter Ulbricht told the workers in his speech and while visiting the exhibition, what Stalinstadt will look like. He pointed to the model of the city, 
and in this gesture lies the solid certainty that the city will arise tomorrow as big and beautiful as it is today thought in the model and in the plan" (G. and R. 1953, 4).

Schmidt did not want or was not able to underline a potential subversive nature of Kretzschmar's painting. Even though it is not as clear as in Mattheuer's later landscapes, Kretzschmar divided its panorama with a diagonal line as Mattheuer did later in his Bratsk painting. For the iconic depiction of an envisioned landscape of industry, housing, and nature, the tree-shadowed avenue linking the hill in the foreground with the city and the power plant in the background serves as a compositional and as a content-related division. It creates a remarkable dynamism in the overall harmony. This diptych view, which can be seen as a distinction between present and future, reality and wish, is mirrored in the black and white clouds above the industrial complexes, in the different people's activities on the hill, and in the dialectic of young and old personified in the family group on the very left where a father is explaining to his child the view of the concrete landscape as well as of future development. To which future and what utopias will the roadwhich the founding generation has cut into the sandy woods of the former East German desert-lead?

However, twenty years after Kretzschmar, a disappearance of the utopian character of the industrialized landscape can be traced even in Socialist landscapes (Gillen 2004, 77). According to Romanus (1978, 90), industrial landscapes of the I950s and I960s, such as Kretzschmar's panorama, had "celebrated the productive relationship of society to nature" with an "unlimited euphoria towards technique"; at the same time, paintings of the same sujet in the I97os would not only "celebrate the actual stand of the rule over nature" but also "reflect the process of the transformation and of the creation of landscapes" (IO2). So these sotzromantic images of landscape meant a break in the genre of landscape painting in the GDR. The qualities of reflection and anticipation of man-nature relationships were embodied in the paintings by Mattheuer, who was inheritor and renewer of the romantic tradition in Socialist landscape painting and who also established himself as one of the most prominent landscape critics in the GDR.

\section{Mattheuer's Landscapes as Deconstruction of the Ideal and the Utopian Relationships of Man and Nature}

After interpreting Kretzschmar's idealistic painting of Eisenhüttenstadt, of which the cultural politics of the party expected the evolution of the genre of Socialist landscape imagery, this chapter is devoted to Mattheuer's attempt for a renewal of that very genre. Not relying on Kretzschmar's stylistic mode but grounded in more subjective romantic visions of a meaningful and emotional relationship of man and nature, Mattheuer's landscapes are genuine artistic expressions of a Socialist romanticism. 


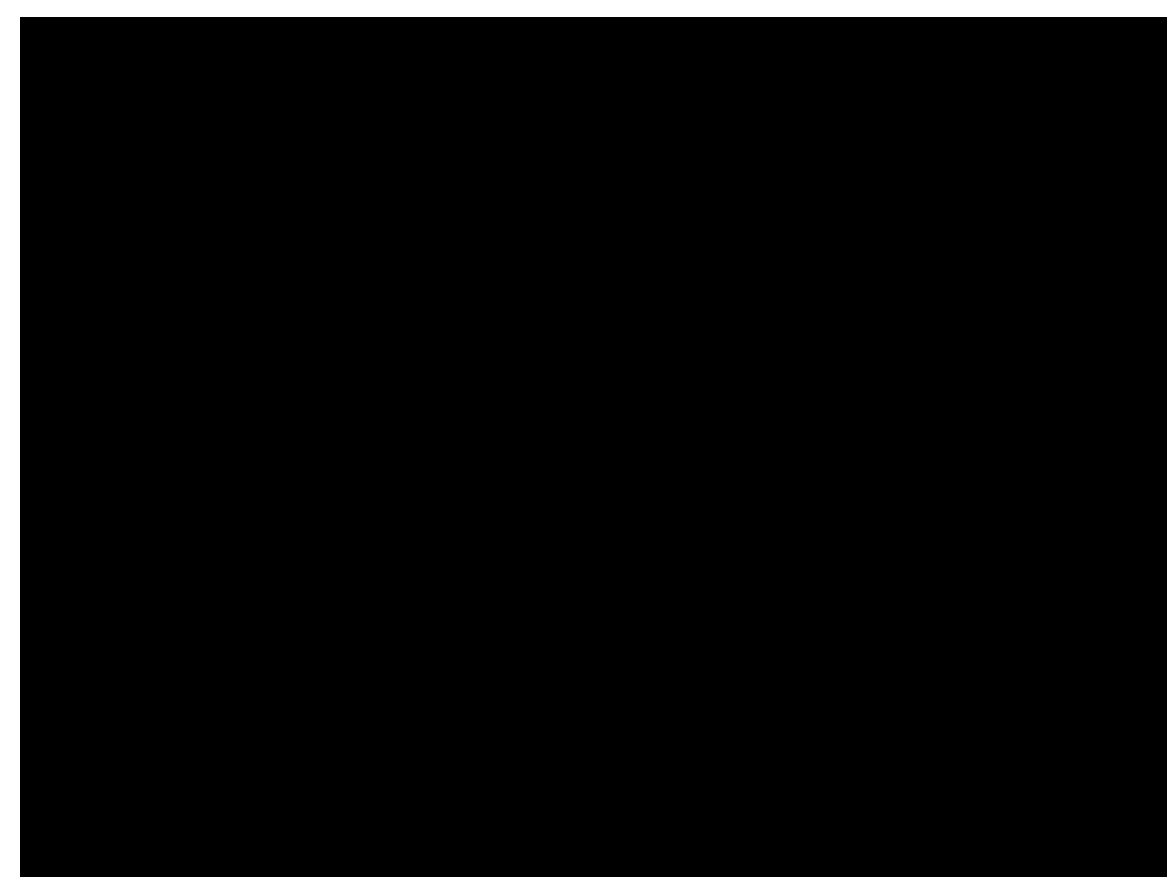

Fig. 23. Wolfgang Mattheuer, Landscape around Bratsk, I967, oil on hardboard, National Gallery, Berlin, Germany. (c) bpk/Nationalgalerie, SMB/Roman März, VG Bild-Kunst, Bonn 2016.

As pointed out earlier in this essay, Mattheuer has been compared to the romantic Friedrich since the early I970s. The Dresden exhibition, which included both artists, as well as the Greifwald conference, proved the close connection between them. Clearly, Mattheuer did not copy Friedrich, but he adapted some motifs, compositional elements, and even the custom of written explanations that Friedrich also used. Friedrich's paintings were all of a conceptual character and not straight records of a direct observation of nature (Stumpel 2008). The same is true of Mattheuer: he also observed nature but then reordered and reorganized elements in an artistic, not naturalistic, way. Interestingly, Mattheuer's first landscape paintings of the I960s were far from Friedrich as a stylistic role model. Only later, in the I970s, did Mattheuer's oeuvre show more and more parallels to Friedrich's artworks.

Mattheuer became known to a broader audience through his painting Landscape near Bratsk (fig. 23), created around 1967 after a state-organized trip to the Siberian city with other colleagues (Sumpf 1968a). It was first presented at the Sixth German Art Exhibition in Dresden in 1967. Since the region around Bratsk and its huge industrial complexes were described with a pathetic tone in official sources as "the 


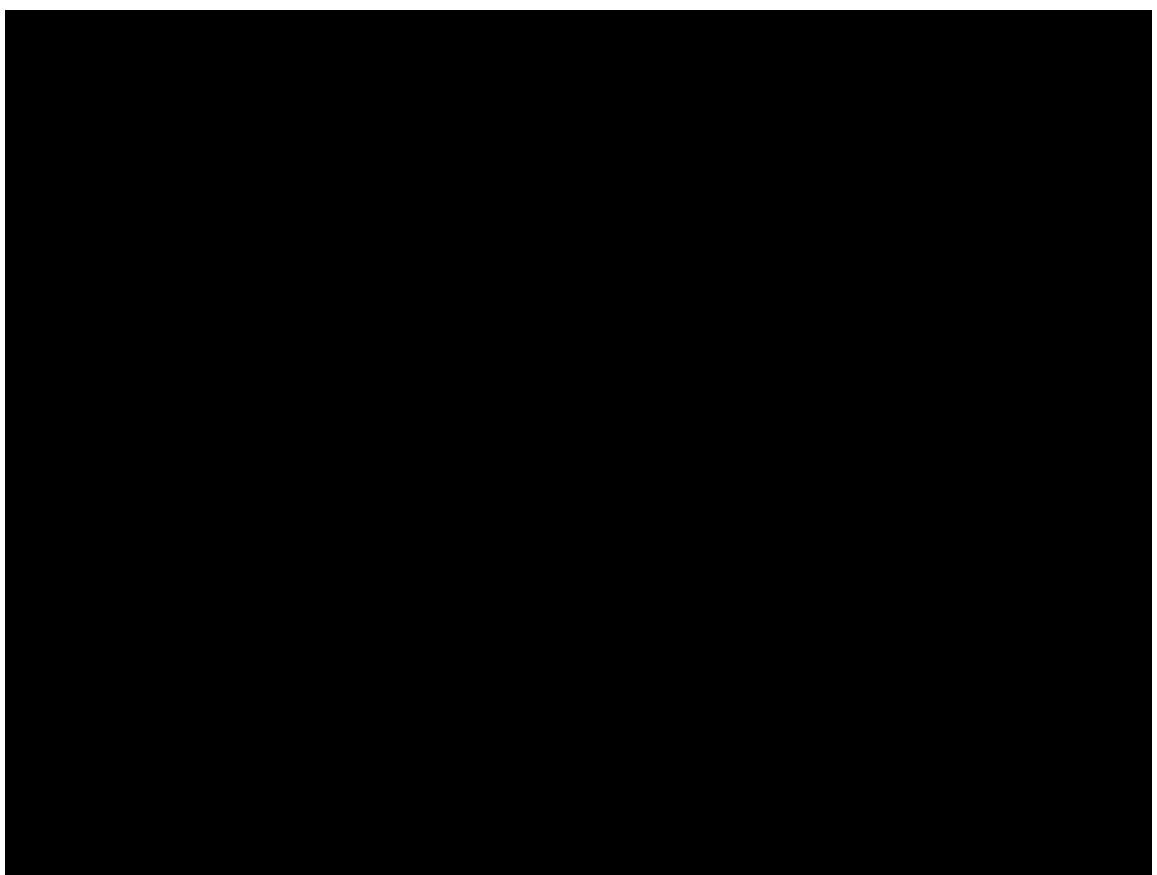

Fig. 24. Willi Neubert, Electric Power Plant of Bratsk, 1966, watercolor. (c) SLUB Dresden/ Deutsche Fotothek/Rudolph Kramer.

electrical heart of Siberia" (fig. 28), ${ }^{\mathrm{I} 3}$ Mattheuer's visual representation offers some surprises when compared with other contemporary paintings of this Siberian place. While Willi Neubert (I920-20II) and Armin Münch (1930-20I3), who accompanied Mattheuer to the USSR and to Bratsk, fulfilled the expectations of SED officials for a noncritical and partisan depiction of transformed landscapes of Socialist reproduction and rule over nature with their paintings (Sumpf I968b; see figs. 24-6), Mattheuer neglected this approach. He focused not so much on industry-which is, in fact, pushed toward the background-but more on the people and their behavior in a transformed, destroyed, and torn landscape (Gleisberg 1970, 23I). This could not have been the intention of the "Socialist Grand Tour" organized by the party, which should have proved the exemplarity of Bratsk as manmade landscape and as source of artistic inspiration. ${ }^{\mathrm{I}}{ }^{4}$

It is obvious that Mattheuer did not celebrate the human triumph over nature or the victory of Soviet Socialism (Hertel 20I4, I24). He shows us a waste-brown desert structured by broken pipelines, streets, and power lines. Beyond the power plant in the background, the sky enigmatically turns from bluish to greyish, and the

13. For the history of the hydroelectric power station at Bratsk see Gestwa (20I0, 32-5).

I4. In fact, many of the big industrialization campaigns in the Socialist world were depicted in the visual arts and spread through media. See Best (20I0). 


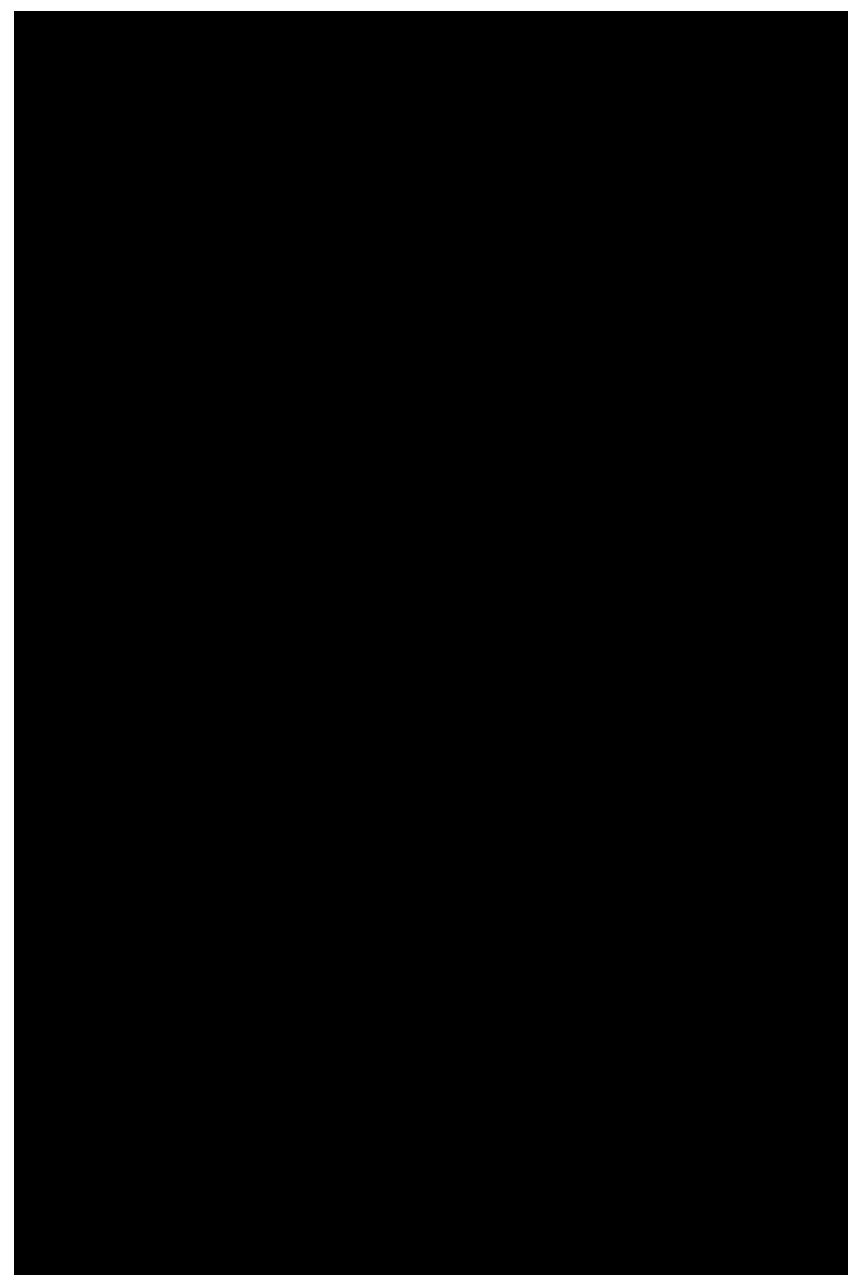

Fig. 25. Willi Neubert, Dam of the Hydroelectric Power Plant of Bratsk, 1966, oil on canvas. (C) SLUB Dresden/Deutsche Fotothek/Rudolph Kramer.

pipeline leading from the plant to the foreground divides the landscape. This compositional element was implemented by Kretzschmar in the late I950s to establish a "diptych view" in his landscape, too. For Mattheuer, the diagonal pipeline stands as visual and symbolic metaphor for the human "cut" through the natural landscape and its consequences. Just as industry or human artifacts in this landscape lack heroism or pathos, the same is true of the human figures. The concentration of human inhabitants of the industrialized environment in the painting was already observed by Mattheuer's contemporaries (Sumpf 1968a, 240). Neubert's and Münch's Bratsk images mainly dealt with the technological and industrial impacts of the huge project; Mattheuer put the inhabitants of this artificial 
environment in the center. This decision links Mattheuer's image to another, also international and highly recognized piece: Viktor Efimovich Popkov's The Builders of Bratsk (fig. 27), which was exhibited at the 1962 Venice Biennale and marked, according to Matteo Bertelé (20I4, I08), "a break with Socialist realist painting, starting from the author's declared intention to free himself from subject painting."

But in Mattheuer's piece, an old lady on the left contemplates; a boy on the right is playing with tanks next to a fallen tree. On the pipeline, two women are balancing while moving forward. At first sight, this picture seems to have nothing in common with Friedrich's sublime landscapes, which celebrated man in nature. It is true that Mattheuer does not really show us a romantic image of landscape, but what links his picture with Friedrich is that Mattheuer presents not only a landscape but also a space of meaningful interaction between humans and nature (Mittelstädt 1953, 30). Meanwhile, the landscape tells us something about human beings. In Bratsk in the late 1960s, the people are isolated, disoriented, and struggling individuals trying to live in a dramatically changed landscape. The separation of industry from the people in Mattheuer's painting could be read as alienation of man from both work and surrounding nature. Of course, partisan interpreters of his work like Romanus $(1978,34)$ denied the alienation, claiming his landscapes are characterized by an "artistically judged contradiction ... with a basic affirmative tendency towards Socialism." And Sumpf (1968a, 240) argued that the youngsters in the painting are conquering the new landscape, as the boy judges "the torn earth of the huge construction site as a romantic arena of his war-games." However one categorizes the person in the painting, whether as alienated or excited, all readings of Mattheuer's landscape have to respect the specific qualities represented in the concentration of the human beings in the landscape and their relationships with nature. With this, Mattheuer pushes a critical perspective on the developments at Bratsk, thematized by Popkov in 1960 on a larger scale linked to the overarching man-nature relationship.

Should this painting have represented a place of the "world-historical realization of man" with which Kühne was so fascinated, or the attractiveness of a "nature which has been designed by the creativeness of man," which the Dictionary of the Arts reported (Landschaft 1971, 854)? Indeed, far from having a romantic aura, Mattheuer's landscape "mirrored a specific relationship to nature," but obviously not in the partisan and dogmatic ways of conventional realistic art in the GDR. It is neither superficially romantic - in the sense of a visual representation of a harmonious and idyllic man-nature relationship—nor superficially Socialist-in the sense of a Gorkian optimistic vision of the triumph of the working class over nature. However, Mattheuer's Bratsk is on a conceptual level romantic as well as Socialist because it visualizes the romantic feeling of the loss of the harmony of man and nature (Lehmann 200I, I88) and because it represents in a genuine style the manmade character of the Siberian landscape as a "sign" or allegory for the ongoing transformations of the "second nature" through civilizational and industrial influences. Or to put it another way, Bratsk as a landscape 


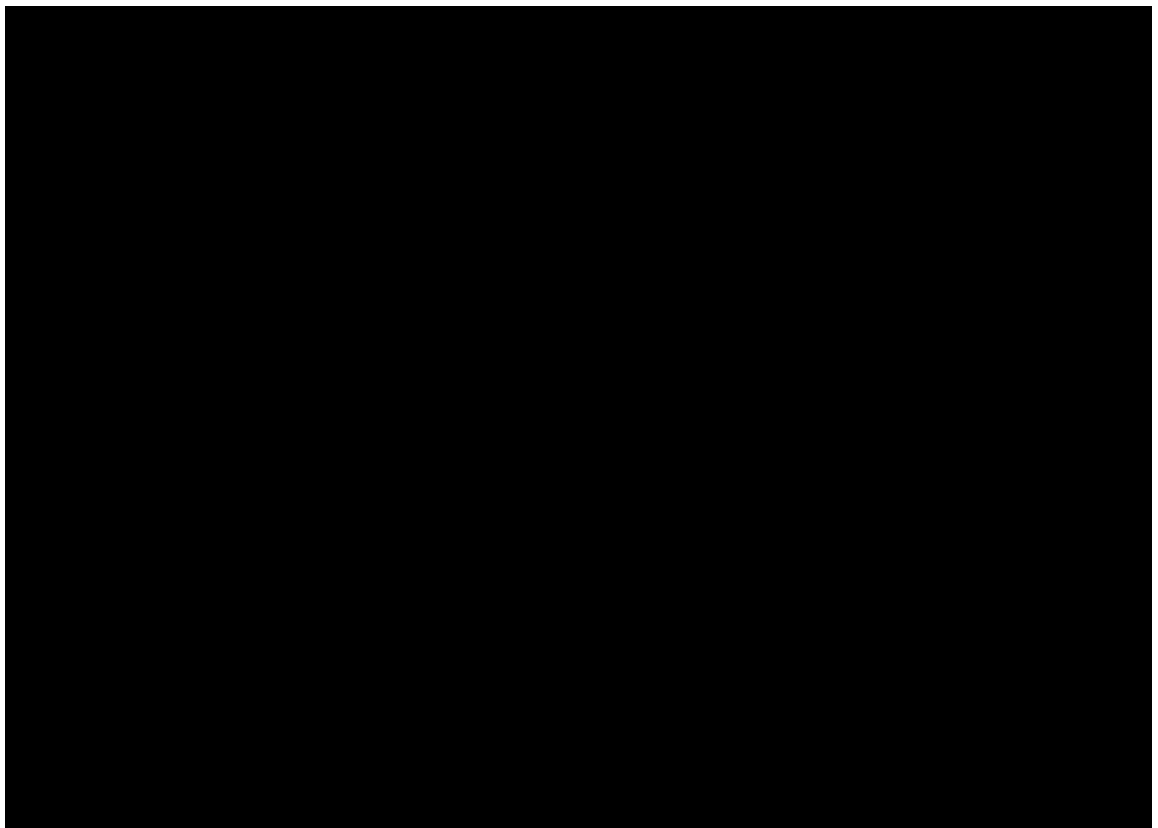

Fig. 26. Armin Münch, Bratsk I (First Draft), 1966, pen, chalk, watercolor, from the graphic cycle Bratsk/Siberia. (c) SLUB Dresden/Deutsche Fotothek/Rudolph Kramer.

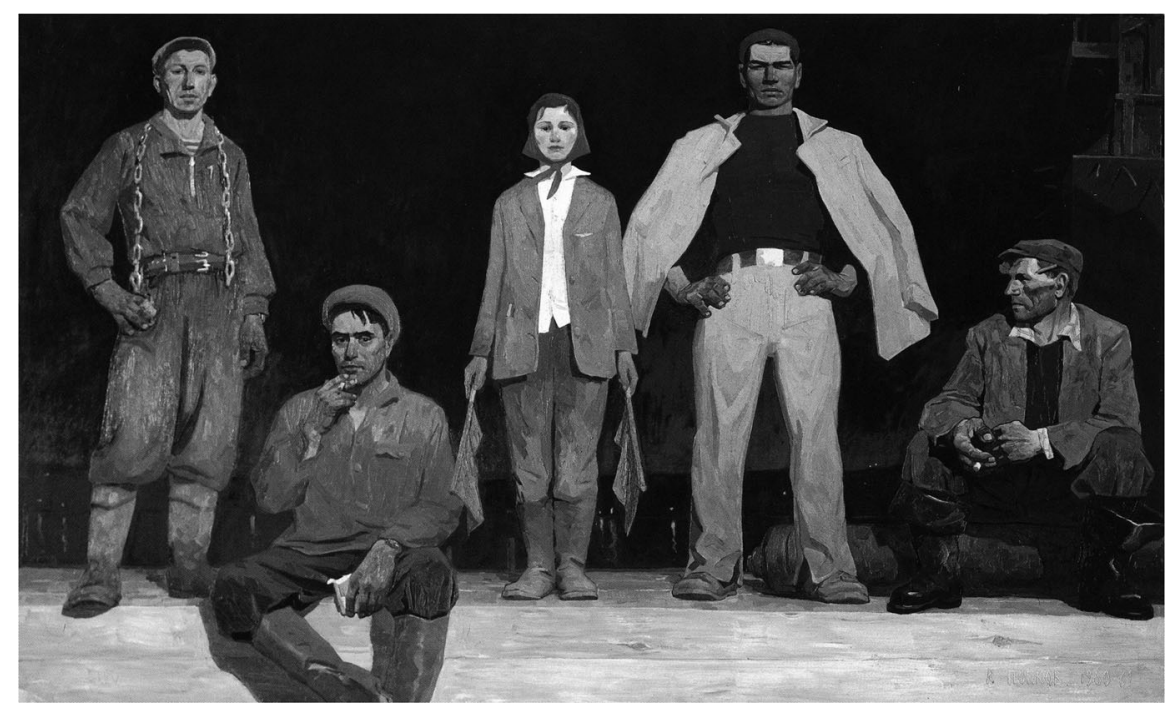

Fig. 27. Viktor Efimovich Popkov, The Builders of Bratsk, 1960, oil on canvas, State Tretyakov Gallery, Moscow, Russia. Photo from the author's archive. 


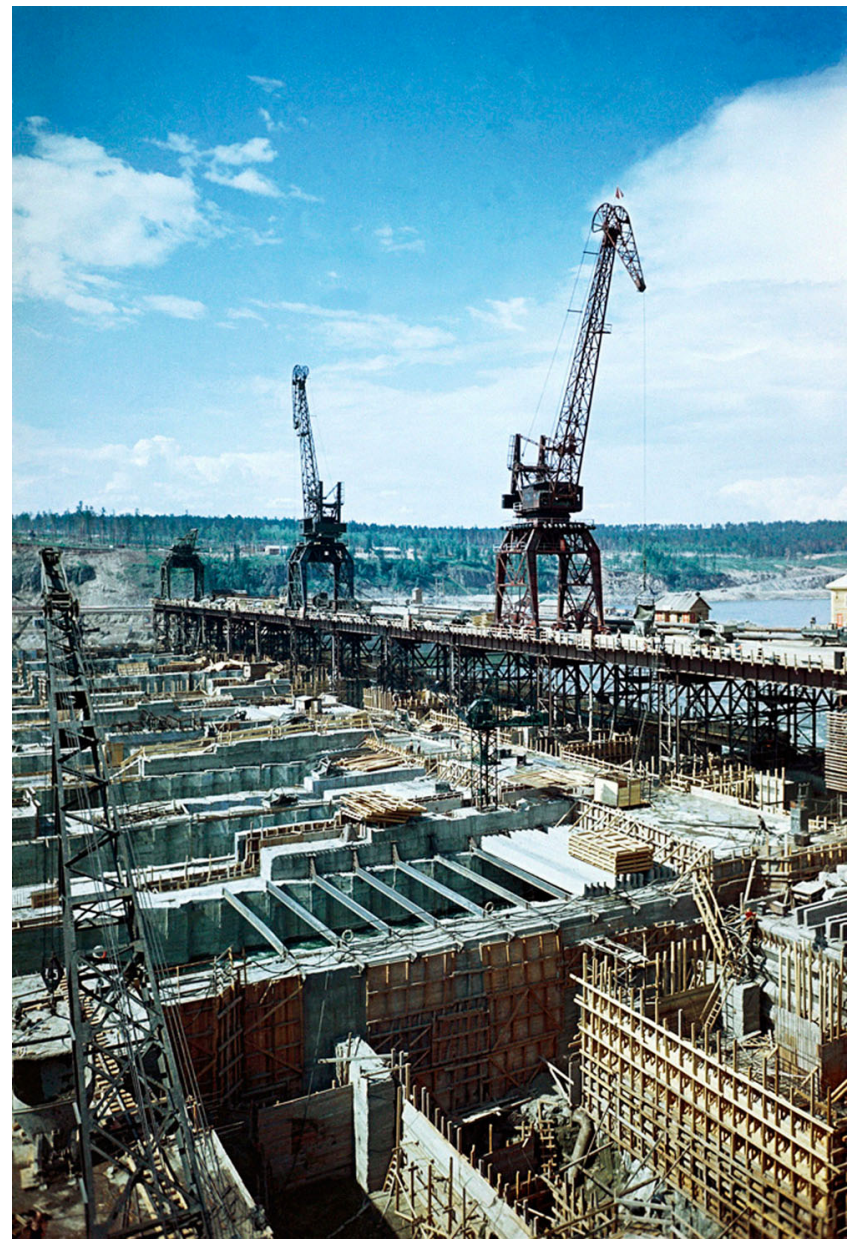

Fig. 28. Building the Bratsk Hydropower Plant, 29 September 1959. (C) RIA Novosti archive, image \#315182/Michael Trahman/CC-BY-SA 3.o.

transformed fundamentally by the Socialist society of the Soviet Union is the mirrored counterpart of Kretzschmar's Eisenhüttenstadt as a utopian, Marxist vision of the East German sandy desert transformed into a new town. Remarkably, both artists chose industrial landscapes to give their romantic/Socialist attitudes adequate expression.

While Kretzschmar painted a vital and bright scene of the growing city of Stalinstadt in the late I950s, Mattheuer showed in his 1974 Friendly Visit to the Lignite Mining (fig. 29) a tortured and deformed landscape. It is the same blue sky and a comparable industrial plantation in the background of both paintings, but Mattheuer brings the central motive-some workers and square-headed party officials 


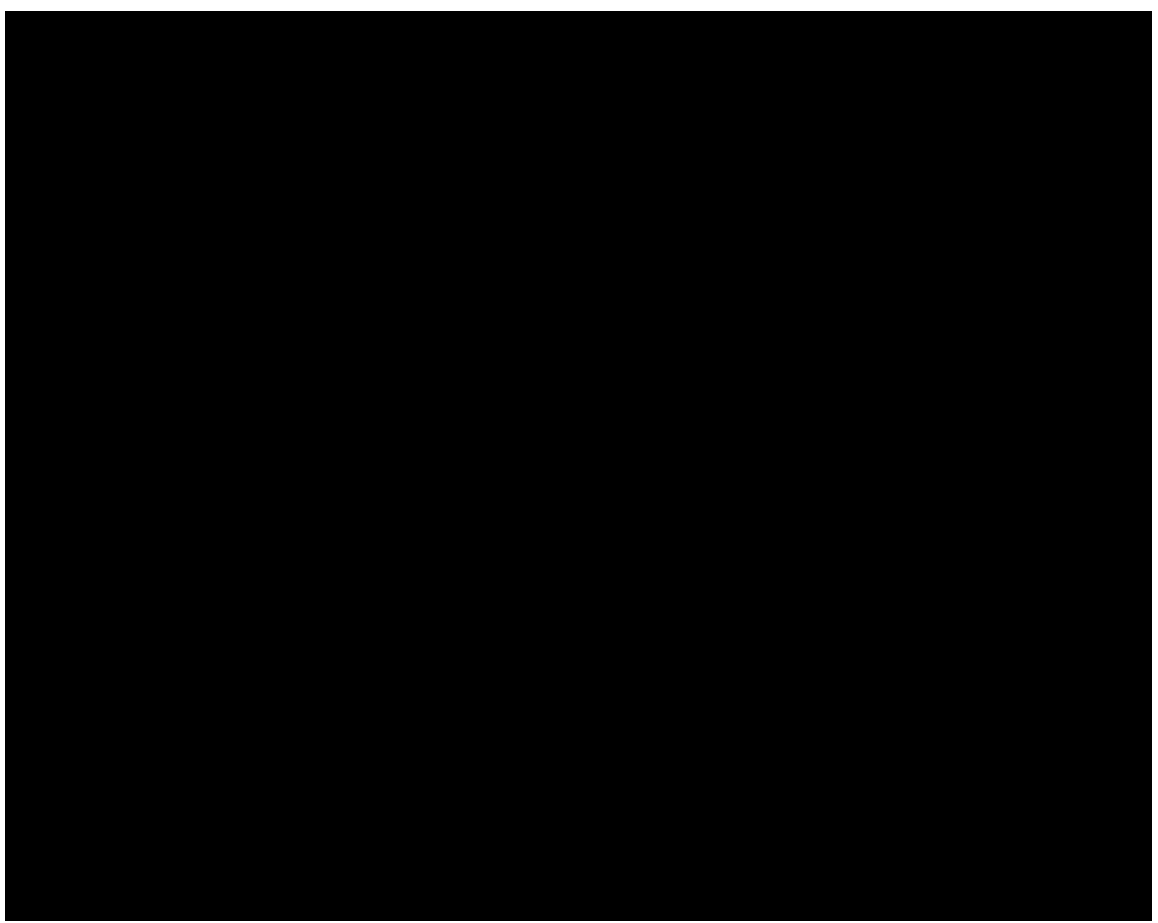

Fig. 29. Wolfgang Mattheuer, Friendly Visit to the Lignite Mining, 1974, oil on hardboard, private collection, Potsdam, Germany. Photo from the author's archive. (c) VG BildKunst, Bonn 2016.

with documents-much closer to the viewer. Not only are the human beings alienated from one another but they also seem to have lost contact with nature. But what nature can be traced in the image at all? Only a small piece of vegetation survives in the foreground in the middle of the brown desert. While Kretzschmar has most likely chosen the panorama format for his utopian vision, Mattheuer presents a "closed" landscape without any perspective into future development. The viewer is not invited to recognize a bright future but is confronted with the very problems of life under Socialism and the ongoing destruction of natural resources in the I970s (Scholz 2009, 475-7).

This painting by Mattheuer can be read as a critique of Socialist environmental politics that aimed to change nature and landscape as a programmatic act, as an "overcoming of the past and its limitations and as overcoming of nature," as Best puts it. ${ }^{15}$ Regarding the partisan viewpoint on the visual arts, Romanus

I5. "It has been especially the idea of planning in a great-a 'geological'-scale, which inspired the visions of future [in Socialism, O.S.]. The alteration of the physical space, for example of rivers, meant the rule of man over nature. Infrastructural major projects are related closely with ideas of 
$(1978,92)$ claimed that the "dominant concept of man and society which arose from an idealized, simplifying imagination of the dialectics of the development of society" is now replaced by a more differentiating approach, but on the other hand he did not recognize the obvious critical elements in Mattheuer's landscapes.

Mattheuer's references to Friedrich's art developed further in the late I970s. As in the previous examples, his Oh Caspar David ... (see fig. 30), with a direct reference to the romantic in the title, is again characterized by the combination of reality and fantasy, of symbolic representation and accurate observation. In this case, Mattheuer forgoes human figures and visible artifacts of human society; only the smoking power plants in the very background are a direct reminder of industrialization. However, what is most important here is, I think, the division into three zones: the brown foreground with a fallen oak, the large central area consisting of regular but artificial hills of dark earth, and the dark greyish sky above. The reference to Friedrich is given not only by the title but also by the tree in the foreground because for Friedrich the oak was a symbol of the German nation and history (Hernand 200I; Grummt 2008). In his Abbey in an Oak Forest (see fig. 3I), the tree and architecture form a commitment to the German culture, symbolized by oaks and gothic ruins (Lehmann 200I, 19I). Following the intensive resource extraction in the GDR, the oak in Mattheuer's painting has fallen and the landscape has been transformed. Now it is not a vital symbol like a tree dominating the scenery but a depressive and monotonous outlook on actually existing Socialism.

Mattheuer was quoting art historical styles, techniques, and motifs as actualization and historicization. Despite his partisan engagement and involvement in Socialist cultural politics in the GDR, Mattheuer formed an artistic opposition against the dogma of Socialist realism as mirroring reality in its revolutionary development. Mattheuer oriented himself toward Friedrich. For him, the category of history was much more than just a formal aspect of his work; it was an attitude toward the presence of actually existing late Socialism. Mattheuer dealt with manipulated and transformed elements of older styles in order to express his view of contemporary issues. Artworks of the I970s and I980s by Mattheuer became "time images" on several levels: they quote the past (style, motifs, technique) by interpreting the present (topic, message), and they envision the future very skeptically. One can observe neither Kretzschmar's open and bright horizons nor the powerful vision of a technocratic utopia in the landscapes of Mattheuer. Panoramic views, stable positions, and clear messages are replaced by highly subjective and enigmatic visions that emphasize the role of the subject viewing the painting. The artistic vision of a connection between industrialization and the overcoming of nature as a symbol of Socialist modernity (Best 2010, I38), which was embodied in Kretzschmar's works, has lost its force of persuasion. Neither an ideological nor a clear

modernity—both as the overcoming of the past and its limitations and as overcoming of nature" (Best 2010, 139). 


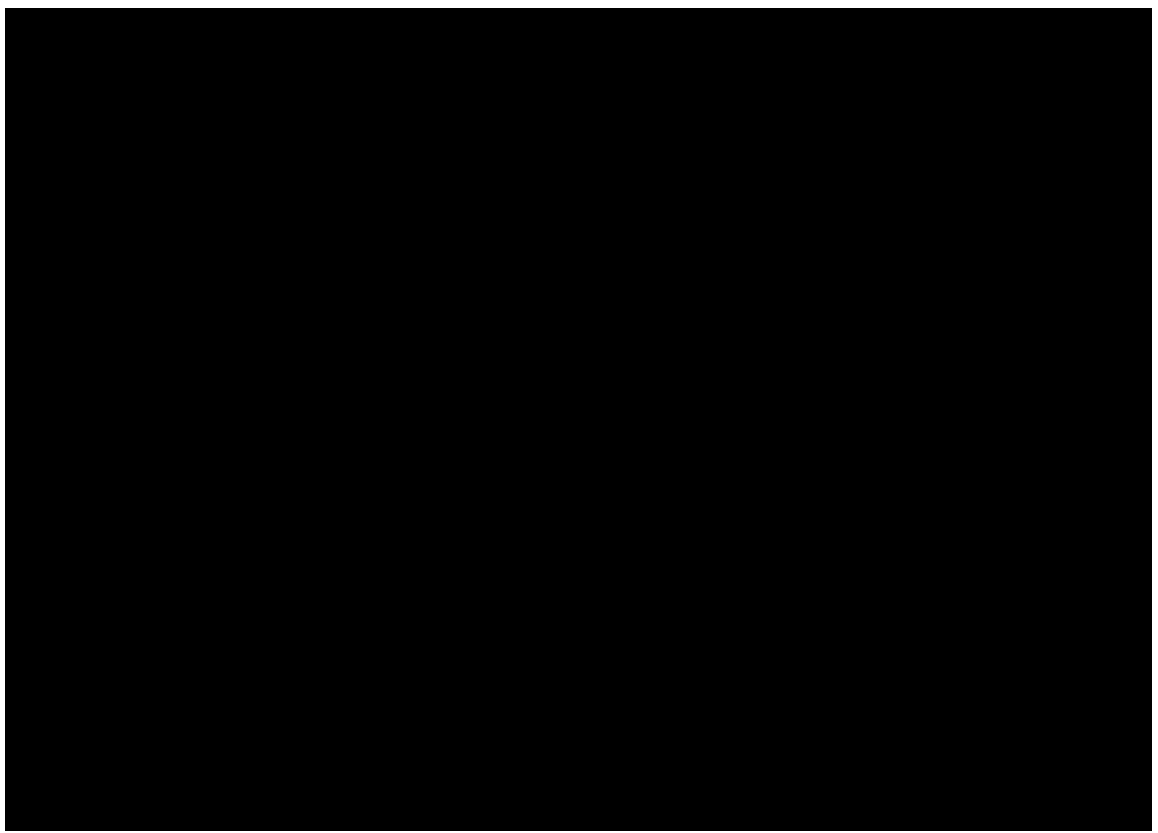

Fig. 30. Wolfgang Mattheuer, Oh, Caspar David ..., I975, oil on hardboard, Mattheuer Foundation, Leipzig, Germany. Photo from the author's archive. (c) VG Bild-Kunst, Bonn 2016.

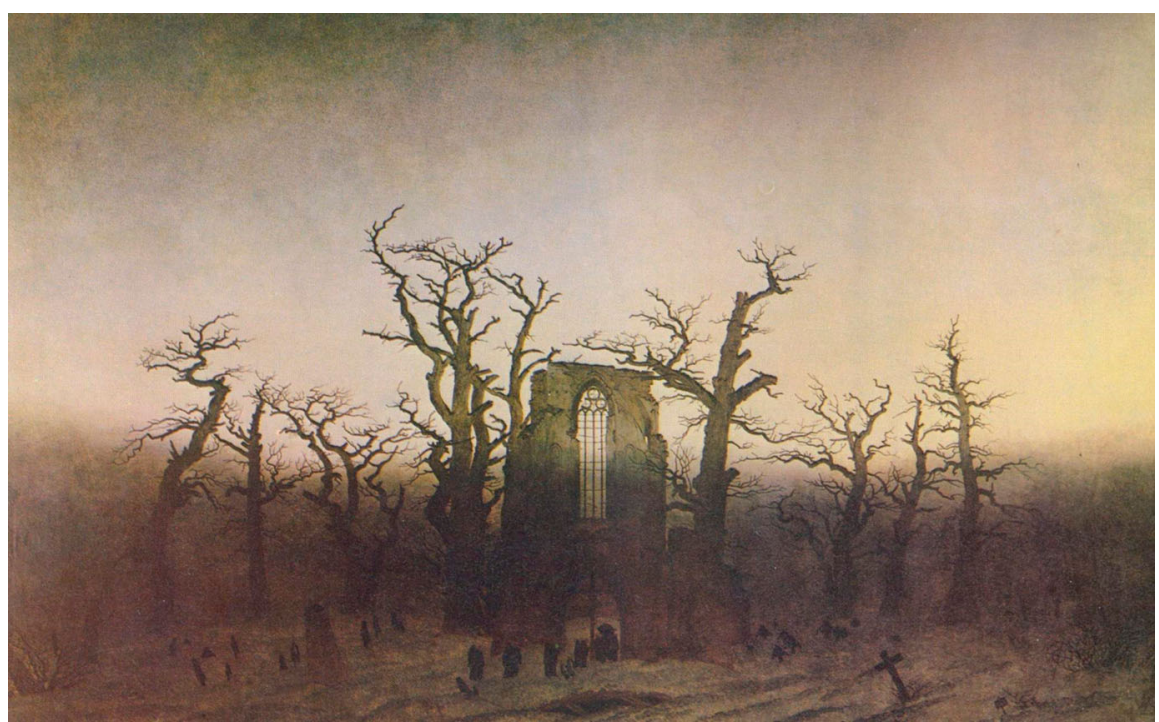

Fig. 3I. Caspar David Friedrich, Abbey in an Oak Forest, I809-I0, oil on canvas, National Gallery, Berlin, Germany. (C) Wikipedia Commons. 
Socialist slogan can be traced in Mattheuer's landscapes; the subject is turned back upon itself, a truly romantic topos.

\section{Conclusion}

This essay has aimed to contextualize the rediscovery of romantic landscape images in the visual arts of the GDR and the emergence of critical voices with regard to the great environmental problems stemming from the ruthless industrialization and the construction of a Socialist society as part of the framework of Sotzromantizm. Intellectuals like Kühne, art historians like Romanus, and artists like Mattheuer were dealing with contemporary issues represented and symbolized in the category of landscape. If Ina Adler (1976, 33I) observed that "Mattheuer understands the space of landscape as expression and status of human transformation and creation, as space of human life and human perfection ... the space of landscape is directly social space," then it becomes clear that the subversive qualities of the symbolic representations of landscapes lie in an emancipatory approach established in the Enlightenment and continued in the romantic era. Throughout art history, philosophy, and politics grounded in Marxism-Leninism, thinkers in the GDR were referring to this idealized vision of landscape as a place of moral complement based on Rousseau, Schiller, or Marx.

However, all of these visual examples are characterized by different approaches to the Socialist landscape, oscillating between subordination of nature to the demands of the Socialist economy and society, on one hand, and the romantic "charging" of nature as space for subjective and emotional interpretations of the present state of society on the other. Future research on the topic of the reception of romanticism should investigate much more deeply the importance of the romantic tradition for German art after World War II in both East and West (Schmitz-Emans 2004, 28-3I).

In this specific case, I suppose that the relevance of landscape paintings in the GDR can be compared to the appearance of romantic elements in art theory, art history, and the visual arts as a dynamic process since the late I960s. This appearance had widespread consequences for the interpretation of the prehistory of art in the GDR (Feist 1974). Plus, it resulted in the circumstance that, especially in the genre of landscape painting, romanticism again became a fruitful source of inspiration for contemporary artists in Socialism. This was extraordinary since romanticism had been criticized for being backward looking and ideologically reactionary. The reception of the German romantic era of the early nineteenth century can therefore be interpreted as part of the broader phenomenon of the historicization of the cultural roots of the GDR. The emphasis on the viewer as autonomous subject and the ambiguity of Mattheuer's landscapes-his landscapes can be read as critique, depictions of romantic sentiments, transfigurations, allegories, or all of them at once (Uhlitzsch 1974,4 )—challenged and questioned Socialism's 
reason in art and its faith in artistic "truth," linking Mattheuer's works with Friedrich's (Busch 200I, 52I). While Friedrich's landscapes lost their spiritual and religious impetus through the Socialist interpretation of his work-which then led to the historicization of his oeuvre-Mattheuer's landscapes, on the other hand, gained pictorial and aesthetic.

Kühne's utopian vision of the repeal of the alienation of man, nature, and landscape in Socialism/Communism and of the "humanization" of the environment, which he had drawn in his essay "House and Landscape," has not come into being. In the very same year that his collection of essays was published, 1985, Kühne killed himself. Only a few years later, the whole Socialist experiment in East Germany collapsed, partly because of the subversive practices of environmental protection groups, which saw the party's and state's failures also represented in the natural devastation and disasters around the country (fig. 32). Ever since,

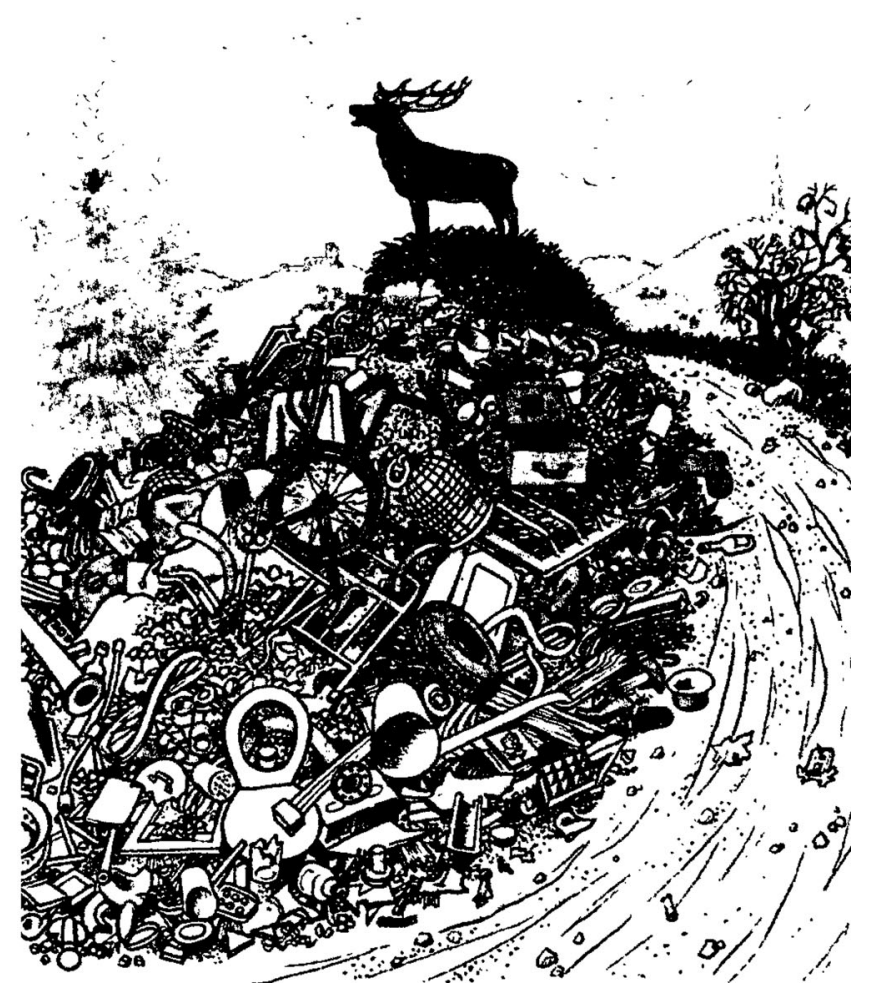

Fig. 32. Great Landscape with Heap, 1985, caricature, Der Spiegel, 30 (1985): 68. Photo from the author's archive. 
Mattheuer's paintings have been interpreted and used for various meanings and aims, whether for celebrations of the Socialist culture of the GDR, as in 1974, or whether as critical expressions on environmental and sociopolitical developments in the 1980s. His images became visual expressions of an actualization of romantic ideas on the power of nature and landscape. Finally — and again — the cultural category of landscape is crucial for understanding how members of the Socialist society of the GDR saw nature and landscape, how they interacted and transformed their environment, and how they envisioned their ideal life within the changing landscapes of Socialism.

\section{Acknowledgments}

This essay is a revised and expanded version of a talk prepared for the 2014 Princeton Conjunction conference "Romantic Subversions of Soviet Enlightenment: Questioning Socialism's Reason," organized and sponsored by the Princeton Institute for International and Regional Studies and the Program in Russian, East European, and Eurasian Studies, Princeton University, New Jersey, 9-IO May 20I4. I want to thank the conference organizers for their gracious invitation to participate in the conference, especially Serguei Oushakine, who gave me extremely useful feedback and thoughtful comments for the essay. I would also like to thank the Central Institute for Art History, Munich, where I worked out the paper during my fellowship in 20I4-6, and especially the two Rethinking Marxism reviewers, Enid Arvidson and Steven Quevedo, for their helpful comments and suggestions on an earlier draft.

\section{References}

Adler, I. 1976. Raum für den Menschen, von Menschen geprägt: Zu Wolfgang Mattheuers Gemälden. Bildende Kunst 24 (7): 329-3I.

Amberger, A. 20I4. Bahro-Harich-Havemann: Marxistische Systemkritik und politische Utopie in der DDR. Paderborn: Schöningh.

Bachmann, M. 1976. Festrede zur Eröffnung der Ausstellung "Caspar David Friedrich und sein Kreis" am 24 November 1974 im Albertinum. In Beiträge und Berichte der Staatlichen Kunstsammlungen Dresden 1972-1975, 7-12. Dresden: Staatliche Kunstsammlungen Dresden.

Beaucamp, E. 2007. Mattheuer and the lessons of the landscape. In Evening, hills, forests, love: The other Mattheuer, by E. Beaucamp, J. E. Howoldt, and A. Hertel, I4-26. Leipzig: Kerber.

Bertelé, M. 20I4. From "youthful fervor" to posthumous tribute: Viktor Popkov at the Venice Biennale (1962, 1982). In Dream reality: Viktor Popkov 1932-I974, ed. G. Barbieri, M. Bertelé, and S. Burini, I07-19. Venice: Terra Ferma.

Best, U. 20I0. Arbeit, Internationalismus und Energie: Zukunftsvisionen in den Gaspipelineprojekten des RGW. In Zukunftvorstellungen und Staatliche Planung im Sozialismus: Die Tschechoslowakei im ostmitteleuropäischen Kontext 1945-1989, ed. M. S. Wessel and C. Brenner, I37-58. Munich: Oldenbourg. 
Busch, W. 200I. Caspar David Friedrich. In Deutsche Erinnerungsorte, ed. E. François and H. Schulze, 3: 5I6-30. Munich: C. H. Beck.

Cosgrove, D., and S. Daniels. 1988. Introduction: Iconography and landscape. In The iconography of landscape: Essays on the symbolic representation, design and use of past environments, ed. D. Cosgrove and S. Daniels, I-IO. Cambridge: Cambridge University Press.

Dalbajewa, B., and A. Dehmer. 20II. Überhöhte Wirklichkeit um 1900: Voraussetzungen der Neuen Sachlichkeit in Dresden. In Neue Sachlichkeit in Dresden: Malerei der zwanziger Jahre von Dix bis Querner, ed. B. Dalbajewa, 58-67. Dresden: Sandstein.

Emmerich, W. 1996. Kleine Literaturgeschichte der DDR. Leipzig: Kiepenheuer.

Feist, P. H. 1974. Romantik und Realismus. In Caspar David Friedrich und sein Kreis, II-2I. Dresden: Staatliche Kunstsammlungen Dresden.

G., S. and D. R. 1953. Wie die erste sozialistische Stadt unserer Republik den Namen Stalin erhielt. Neues Deutschland, 9 May, 4.

Gestwa, K. 20I0. Die Stalinschen Großbauten des Kommunismus: Sowjetische Technik- und Umweltgeschichte 1948-1967. Munich: Oldenburg.

Gillen, E. 2004. Gestrandete Utopien: Landschafts- und Strandbilder als Gesellschaftskritik. In Zwischen Himmel und Erde: Landschaftsbilder aus der DDR, ed. S. Tippach-Schneider, 7382. Beeskow: Kunstarchiv Beeskow.

Gleisberg, D. 1970. Weggefährten: 25 Künstler aus der DDR. Dresden: Verlag der Kunst.

Goeschen, U. 20oI. Vom sozialistischen Realismus zur Kunst im Sozialismus: Die Rezeption der Moderne in Kunst und Kunstwissenschaft der DDR. Berlin: Duncker und Humblot.

Grummt, C. 2008. Der Wald bei Caspar David Friedrich: Kunst als religiöse Umdeutung der Natur? In Der Wald als romantischer Topos, ed. U. Jung-Kaiser, I07-28. Bern: Peter Lang.

Hager, K. 1975. Engels' "Dialektik der Natur" und die Gegenwart. Berlin: Dietz.

Häsler, H. 1966. Ich baute das Hüttenwerk mit auf. Neues Deutschland, 25 January, 5.

Heinzelmann, M. 1997. Die Landschaftsmalerei der Neuen Sachlichkeit und ihre Rezeption zur Zeit des Nationalsozialismus. Frankfurt am Main: Peter Lang.

Hermand, J. 200I. Caspar David Friedrichs "Eiche im Schnee" im Umkreis der Befreiungskriegsthematik. In Die Zukunft der Alten Meister, ed. E. Mai, 2I7-42. Cologne: Böhlau.

Hertel, A. 20I4. Wolfgang Mattheuer: Die politische Landschaft. Marburg: Tectum.

Horlamus, E. 1963. Mit Dora in Eisenhüttenstadt. Neues Deutschland, 2I September, I2.

Howoldt, J. 2007. Wolfgang Mattheuer and the romantic landscape. In Evening, hills, forests, love: The other Mattheuer, by E. Beaucamp, J. E. Howoldt, and A. Hertel, 50-60. Leipzig: Kerber.

Iden, P. 2002. Es geht um das Bild der Welt-Wolfgang Mattheuer über seine Kunst in der alten und der neuen Zeit. In Wolfgang Mattheuer-Retrospektive: Gemälde, Zeichnungen, Figuren, ed. I. Mössinger and K. Drechsel, 74-9. Leipzig: Seemann.

Imig, W. 1974. Caspar David Friedrich: Bildende Kunst zwischen der Französischen Revolution von I789 und der bürgerlich-demokratischen Revolution von I848. I. Greifswalder RomantikKonferenz anläßlich der Caspar-David-Friedrich-Ehrung in der Deutschen Demokratischen Republik 1974. Ed. W. Imig. Greifswald: Universitätsverlag Greifswald.

Kucher, K. 2007. Der Gorki-Park: Freizeitkultur im Stalinismus I928-I94I. Cologne: Böhlau.

Kuhirt, U. 1958. Mensch und Arbeit im neuen Verhältnis. Bildende Kunst 4 (6): 227-32.

. 1975. Ein "ungewöhnlicher" Realismus? Gedanken zum Werk Wolfgang Mattheuer. Bildende Kunst 23 (6): 28I-5.

Kuhrmann, A. 2006. Der Palast der Republik: Geschichte und Bedeutung des Ost-Berliner Parlaments- und Kulturhauses. Petersberg: Michael Imhof. 
Kühne, L. 1985. Haus und Landschaft: Zu einem Umriß der kommunistischen Kultur des gesellschaftlichen Raumes. In Haus und Landschaft: Aufsätze, ed. L. Kühne, 9-46. Dresden: Verlag der Kunst.

Landschaft. 197I. Lexikon der Kunst, I:850-4. Leipzig: Seemann.

Lehmann, A. 200I. Der deutsche Wald. In Deutsche Erinnerungsorte, ed. V. E. François and H. Schulze, 3: I87-200. Munich: C. H. Beck.

Löther, R. 2007. Bemerkungen zum Verhältnis von Natur, Mensch und Gesellschaft in der Geschichte der marxistischen Philosophie. In Umweltschutz in der DDR, ed. $\mathrm{H}$. Behrens, I:I9I-9. Munich: Oekom.

Lukács, G. 1980. The destruction of reason. London: Merlin.

Magritz, K. 1953. Die Wahrheit der Kunst ist die Wahrheit des Lebens. Bildende Kunst I (2): 3444 .

Malycha, A., and P. J. Winters. 2009. Geschichte der SED: Von der Gründung bis zur Linkspartei. Bonn: Bundeszentrale für Politische Bildung.

Männel, G. 1989. Dresden-Gostritz-Friebelstraße: Landschaft und Reisen. In Bernhard Kretzschmar 1889-1989, 37-62. Dresden: Staatliche Kunstsammlungen Dresden.

Mansfeld, H. 1953. Zur dritte Deutschen Kunstausstellung. Bildende Kunst I (3): 20-7.

Mattheuer, W. 2002. Aus meiner Zeit: Tagebuchnotizen und andere Aufzeichnungen. StuttgartLeipzig: Hohenheim.

Mittelstädt, K. 1953. Die deutsche Landschaftsmalerei: Zu einer Ausstellung der LucasCranach-Kommission in Berlin. Bildende Kunst 6 (I): 30-4.

Moeck, R. 2005. Zum marxistischen Naturverständnis in den 6oer Jahren. In Denkversuche: DDR-Philosophie in den 6oer Jahren, ed. H.-C. Rauh and P. Ruben, 133-56. Berlin: Links.

Morozov, A. 2003. Socialist realism: Factory of the new man. In Dream factory Communism: The visual culture of the Stalin era, ed. B. Groys and M. Hollein, 64-84. Ostfildern-Ruit: Hatje Cantz.

Müller, H. 1953. Ludwig Richter zum einhundertfünfzigste Geburtstag: Ein Abriss seines Lebens und Werkes. Bildende Kunst I (5): IO-20.

Natur. 1973. In Lexikon der Kunst, 3:502-4. Leipzig: Seemann.

Palme, P. 1974. Zur Romantikrezeption in der DDR-Kunst: Beobachtungen am Werk von Wolfgang Mattheuer. In Caspar David Friedrich: Bildende Kunst zwischen der Französischen Revolution von 1789 und der bürgerlich-demokratischen Revolution von I848. I. Greifswalder Romantik-Konferenz anläßlich der Caspar-David-Friedrich-Ehrung in der Deutschen Demokratischen Republik 1974, ed. W. Imig, I38-4I. Greifswald: Universitätsverlag Greifswald.

Pracht, E. 1975. Einführung in den sozialistischen Realismus. Berlin: Dietz.

Romanus, P. 1976. Vielfältige Wirkungsmöglichkeiten eines Genres: Zu Werken der Landschaftsmalerei im Palast der Republik. Bildende Kunst 24 (9): 446-9.

- 1978. Zur gesellschaftlichen Funktion zeitgenössischer Werke der Landschaftsmalerei der DDR. Berlin: Akademie für Gesellschaftswissenschaften beim ZK der SED.

Schmidt, D. 1970. Bernhard Kretzschmar. Dresden: Verlag der Kunst.

Schmitz-Emans, M. 2004. Theories of romanticism: The first two hundred years. In Nonfictional romantic prose: Expanding borders, ed. S. P. Sondrup and V. Nemoianu, I336. Amsterdam: John Benjamins Publishing.

Scholz, M. F. 2009. Die DDR 1949-1990. Stuttgart: Klett-Cotta.

Schönemann, H. 1988. Wolfgang Mattheuer. Leipzig: Seemann.

Schulze, I. 1974. Gedanken vor dem siebte Kongreß des Verbandes Bildender Künstler: Zwischen Feld und Straße umgeschaut, zur Entwicklung unserer Landschaftsmalerei. Neues Deutschland, 25 May, II. 
Seng, E.-M., and R. Saage. 20I2. Utopie und Architektur. In L'Architecture Engagée: Manifeste zur Veränderung der Gesellschaft, ed. W. Nerdinger, IO-37. Munich: Detail.

Staatliche Kunstsammlungen Dresden. 1974. Caspar David Friedrich und sein Kreis. Dresden: Staatliche Kunstsammlungen Dresden.

Stephanowitz, T. 1954. Entwicklung und Ergebnisse: Fünf Jahre Kunst in der Deutschen Demokratischen Republik. Bildende Kunst 2 (5-6): 3-II.

Stumpel, J. 2008. The romanticism of Caspar David Friedrich. In Caspar David Friedrich $\&$ the German romantic landscape, ed. V. Boele, 40-55. Aldershot: Lund Humphries.

Sumpf, G. 1968a. Landschaft und Industrie: Zu einigen Werken auf der sechste Deutschen Kunstausstellung. Bildende Kunst I6 (5): 239-43.

- I968b. Das Mensch-Technik-Problem in neuen Arbeiten von Willi Neubert. Bildende Kunst I6 (I): 9-I2.

Tippach-Schneider, S. 2004. Zwischen Himmel und Erde: Streifzüge zu Themen der Ausstellung. In Zwischen Himmel und Erde: Landschaftsbilder aus der DDR, ed. S. Tippach-Schneider, 9-24. Beeskow: Kunstarchiv Beeskow.

Town of Young Blood and Iron. 1963. London Times, 4 July, Io.

Uhlitzsch, J. 1974. Bilder, die zum Denken herausfordern: Wolfgang-Mattheuer-Ausstellung in Dresden. Neues Deutschland, 26 November, 4.

Vaatz, A. 1996. Umweltpolitik. In Lexikon des DDR-Sozialismus: Das Staats- und Gesellschaftssystem der DDR, ed. R. Eppelmann, 2:859-69. Paderborn: Schöningh.

Vagt, K. 2013. Politik durch die Blume: Gartenbauausstellungen in Hamburg und Erfurt im kalten Krieg (I950-1974). Munich: Dölling and Galitz.

Warnke, M. 1995. Political landscape: The art history of nature. Cambridge, Mass.: Harvard University Press.

Whyte, I. D. 2002. Landscape and history since 1500. London: Reaktion Books.

Zuschlag, C. 1999. Hinter den sieben Bergen: Wolfgang Mattheuer-Malerei als Selbstbefragung. In Das Kunstwerk als Geschichtsdokument: Festschrift für Hans-Ernst Mittig, ed. A. Tietenberg, 219-36. Munich: Klinkhardt und Biermann. 